Hrvoje Jošić*

Maja Bašić ***
JEL Classification: F14, F15

Original scientific paper

https://doi.org/10.32910/ep.72.4.1

\title{
TRADE CREATION AND TRADE DIVERSION EFFECTS FROM CROATIA'S CEFTA AND EU MEMBERSHIP
}

This paper provides a detailed empirical study of trade creation and trade diversion effects arising from Croatia's two regional trade agreements, the Central European Free Trade Agreement (CEFTA) and the European Union (the EU). It offers a foundation for discussion about future trade policies in terms of benefits and drawbacks from those regional trade agreements. Croatia's imports, exports and total trade flows with 180 trading partner countries were examined for the period of 2000 - 2016. Cross-country panel regression using gravity model of international trade assessed pooled OLS, fixed and random effects, as well as more robust Tobit and PPML estimator models. The random effects model found positive effects of CroatiaCEFTA integration evident in trade creation in imports, exports and total trade flows. Croatia-EU integration exhibits no significant effect of trade creation in neither imports, exports nor total trade flows. Nonetheless, there is a trade diversion effect in cases of imports and total trade flows. In the Tobit model CEFTA created trade in imports, exports and total trade flows, while the EU diverted trade in imports and total trade flows. Finally, the robust PPML estimator found that: (1) CEFTA membership created trade in imports, exports and total trade flows, and (2) the EU membership diverted trade in imports and exports, and created trade in total trade flows.

Keywords: trade creation; trade diversion; Croatia; CEFTA; EU; gravity model

*H. Jošić, PhD, Associate Professor, University of Zagreb, Faculty of Economics and Business Zagreb (e-mail: hjosic@efzg.hr).

** M. Bašić, PhD, Teaching associate, University of Zagreb, Faculty of Economics and Business Zagreb (e-mail: mbasic1@ net.efzg.hr). The paper was received on 28.01.2019. It was accepted for publication on 12.05.2020. 


\section{INTRODUCTION}

The Republic of Croatia has been undergoing its last period of economic transition from the socialist to the capitalist economic system that started in 1991 with the War for Independence from SFR Yugoslavia. It is a small open economy that is a WTO member since 2000; was a member of the Central European Free Trade Agreement (CEFTA) between 2002 and 2013, whenafter it joined the European Union (the EU). WTO's multilateral trade agreements apply to Croatia's trade with the rest of the world, while regional trade agreements apply to Croatia's trade with CEFTA members between 2002 and 2013, and the EU member states between 2013 and 2016.

This paper is an in-depth study of trade creation and trade diversion effects from Croatia's membership in CEFTA and the EU for the period 2000-2016, i.e., period of memberships in both regional trade agreements, which have not been previously exhaustively studied. Moreover, this study is important from policy analysis perspective relating to Croatia's trade, which was growing by $5.13 \%$ in 2017 compared to the world trade growth of $1.5 \%$, and is mainly attributed to the growth of trade in services (WITS, 2019).

The objective of this paper is to examine the welfare effects stemming from Croatia's two regional trade agreements: (1) CEFTA and (2) the EU. The purpose of this study is to shed a light on the contemporary challenges arising from a small open economy's existing trade flows, whose main trading partners, Germany and Italy, are both the EU member states. Hence, contribution of this paper is twofold. Firstly, it provides a detailed empirical assessment of the Republic of Croatia's accession into the two regional trade agreements, CEFTA and the EU. Previous studies used a gravity model to examine the effects of economic integration only on Croatian merchandise trade (e.g., Ranilović, 2017). By using a cross-country panel regression analysis (POLS, FE, RE, PPML and Tobit models) based on a gravity model of trade of 180 Croatian bilateral trade partner countries, this study accounts for country-pair specificities and time invariant characteristics of data in the presence of zero trade flows. Secondly, this study provides a foundation for discussion about future trade policies in terms of benefits and drawbacks from the regional trade agreements, especially Croatia's position within the European Union.

This paper analyses trade creation and trade diversion effects of Croatia's CEFTA and EU membership based on the following hypothesis:

H1: Accession of Croatia to CEFTA and the EU had positive effects on Croatia's total trade flows.

Hla: Accession of Croatia to CEFTA and the EU led to positive trade creation effects. 
HIb: Accession of Croatia to CEFTA and the EU had significant negative trade diversion effects.

There are seven sections of this paper. After the introductory section, the second section explains theoretical aspects of modelling trade effects, i.e. trade creation and diversion effects of customs union creation. The third section consists of a literature review of previous empirical studies on trade creation and trade diversion. Graphical representation of Croatia's trade relations with the EU, CEFTA and rest of world are illustrated in the fourth section. Methodology and data used are explained in the fifth section. Results of an econometric analysis and discussion of results are given in the sixth section. The last section contains concluding remarks, policy recommendations, limitations to our study and directions for future research.

\section{MODELLING TRADE EFFECTS OF CUSTOMS UNION: TRADE CREATION AND TRADE DIVERSION}

After World War II, trade liberalisation took forms of multilateral and preferential regional trade agreements. Multilateral agreements benefit all countries involved while regional trade agreements benefit only specific countries in the agreement (Teteryanikova, 2018). Trade agreements that benefit only specific countries of the agreement are the result of the asymmetries in countries' trade patterns. Baldwin (2016) finds that preferential trade liberalisation's ability to protect investment and intellectual property aligns it more closely with the challenges that modern trade faces, rather than a multilateral trade liberalisation that is enabled by World Trade Organisation (WTO). Additionally, regional trade agreements facilitate small open economy's competitiveness because they enable economies' inclusion into regional value chains (Kar, 2018; Martin Mayoral, Moran Carofiilis \& Cajas Guijarro, 2016; Majkovič, Bojnec \& Turk, 2007). The importance of regional trade agreements is evident in their increasing amount. On 26 January 2019, 310 regional trade agreements were in force in the world, which is 12 more than 297 in May 2018 (WTO, 2019).

Balassa (1961) differentiates between different types of economic integrations depending on the level of economic and political complexity: free trade areas, customs unions, common markets, and economic and monetary union. Free trade areas (FTA) arise as a result of abolition of tariffs between two or more trading countries in which countries retain their own customs structure in trade with non-member countries. In cases in which customs duties vary, there exists a risk that goods coming from outside of the FTA area will be imported into a country 
with higher customs duties indirectly through a country with low customs duties, which is called trade deflection. The certificate of origin solves the problem of trade deflection. Common market enables a free movement of labour and capital in addition to the customs union, while economic and monetary union is the highest form of economic integration as it incorporates joint economic and monetary policy (Balassa, 1961).

Customs union uses a common external tariff on trade with non-members of the union in addition to the abolition of tariffs between two or more trading countries (Balassa, 1961). Jacob Viner in his 1950 paper "The Customs Union Issue" explains positive and negative welfare effects of customs unions (Viner, 1950). Positive effects of trade creation occur when domestic production is replaced with imports of cheaper products of a more efficient producer from the customs union. Negative effects of trade diversion happen when previously imported cheaper products are replaced with more expensive products from the customs union. The welfare effects of a small open economy in a customs union are illustrated in Figure 1.

Figure 1 .

\section{MICROECONOMIC MODEL OF A CUSTOMS UNION FOR A SMALL OPEN ECONOMY.}

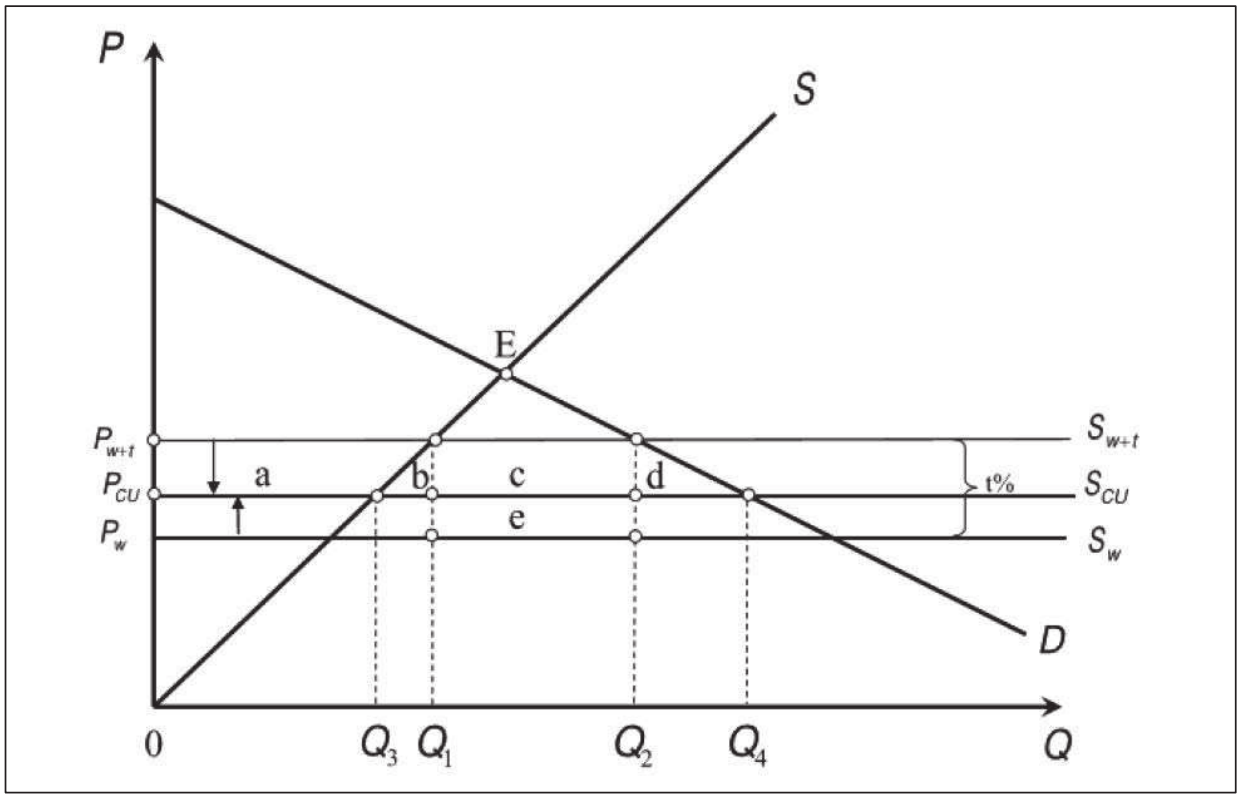

Source: Viner (1950) 
Figure 1 illustrates Viner's partial equilibrium model. Home economy, partner economy and the rest of the world trade is possible under the model. A small open economy cannot influence price of goods on the world market $\left(\mathrm{p}_{\mathrm{w}}\right)$. As a small open economy imports goods from the rest of the world based on price $p_{w}$, when it imposes tariffs to imports the price of imports increase to $p_{w+t}$ and the quantity of imports decreases. Price of imports from a partner economy from the customs union $\left(p_{C U}\right)$ is lower than the price of imports from the rest of the world. Trade creation and diversion effects occur because the price of imports does not fall for the full amount to the world price $p_{w}$. Since the price has fallen from $\mathrm{p}_{\mathrm{w}+\mathrm{t}}$ to $\mathrm{p}_{\mathrm{CU}}$, the consumer surplus increases, producer surplus decreases and income is redistributed from producers to consumers, whereby government lost tariff revenues. Trade creation effect is larger than the trade diversion effect if consumers gain more than the government and produces lose. In that case a small economy benefits from the customs union.

\section{PREVIOUS EMPIRICAL STUDIES ON TRADE CREATION AND TRADE DIVERSION EFFECTS}

Welfare effects are the result of the differences between preferential and general tariff rates, i.e. tariffs from imports from countries that are not member of trade agreements (Urata \& Okabe, 2010; Taguchi, 2015), trading economies' economic and political systems (Michalopoulos \& Tarr, 2004). Specifically, welfare effects of trade depend on the types of products traded, analysed time periods and bilateral trading partners (Fukao, Okubo \& Stern, 2002; Eicher, Henn \& Papageorgiou, 2008; Ghazalian, 2017). Variations in trade creation effects are attributed to the effectiveness in their implementation (Ngepah \& Udeagha, 2018) and anticipatory effects preceeding their implementation (Mölders \& Volz, 2011).

Positive trade creation effect has been found in the case of Pakistan-China free trade agreement (Uzair \& Nawaz, 2018), African economies of ECOWAS (Lugman, Abu Bakar \& Izraf, 2016; Deme \& Ndrianasy, 2017), the Economic and Monetary Community of Central Africa, Southern African Development Community, Southern African Customs Union, and West African Economic and Monetary Union (Ngepah and Udeagha, 2018), Andean Community and Central American Common Market (Martin Mayoral, Moran Carofiilis \& Cajas Guijarro, 2016), ASEAN and China (Yang \& Martínez-Zarzoso, 2013; Taguchi, 2015). Moderately positive trade creation effect was exhibited in the case of the East African Community customs union (Buigut, 2016). Trade creation effect exceeds trade diversion in Common Market of the South America (De Boyrie \& Kreinin, 2016) 
and Turkey-EU customs union in particular sectors (Karaman \& Ozkale, 2006; Magee, 2016). Although Canada-United States Free Trade Agreement (CUSFTA) had predominant trade creation effects (Clausing, 2001), NAFTA exhibits mixed effects that are sector- and time-depending (Morais \& Bender, 2006; Susanto, Parr Rosson \& Adcock, 2007; Martin Mayoral, Moran Carofiilis \& Cajas Guijarro, 2016).

In the European Common Market trade creation is greater than trade diversion due to intra-industry specialisation and rationalisation of production (Balassa, 1974), even in cases of uncertainty (Eicher, Henn \& Papageorgiou, 2008). Regional trade agreements in Europe have been predominantly trade creating, with the exceptions of Central and Eastern European countries and Euro-Mediterranean Agreements with Southern Mediterranean countries (Kendogan, 2005; Urata \& Okabe 2010).

Economic growth in Central and Eastern European countries was facilitated by capital accumulation and market expansion that followed their accession into the European Union (Bilenko, 2013). Trade agreements between Western Balkan countries had a limited impact on their trade (Damijan, de Sousa \& Lamotte, 2006). The example of Slovenia shows that CEFTA was trade creating because of domestic demand rather than because of a reduction in tariffs (Damijan \& Masten, 2002). Similarly, accession to the European Union's single market in 2004 enabled trade creation effects in Slovenia's agricultural sector (Majkovič, Bojnec \& Turk, 2007) and manufacturing products (Majcen, Verbič \& Knežević, 2007). Ćudina and Sušić (2013) examined the expected impact of Croatia's accession to the European Union on the terms of trade with CEFTA 2006 signatory countries, while Ranilović (2017) depicted positive trade impact of Croatia's European Union accession, and a non-robust Croatia's membership in CEFTA. Due to its close trade relations with CEFTA member countries, it was interesting to study Croatia's accession to the European Union Customs Union (EUCU) (Jošić \& Jošić, 2013). In 2019 Croatia is awaiting its entrance into the Exchange Rate Mechanism II. Introduction of a single currency should increase stability and prevent exchange rate fluctuations of Croatian highly Euroised small open economy (Government of the Republic of Croatia and the Croatian National Bank, 2018). Moreover, there is an evidence of a positive trade creation effect of financial opening between the EU member states that adopted the single currency (Esposito, 2017). Hence, this paper studies trade creation and trade diversion effects from Croatia's CEFTA and EU membership prior to the introduction of the single currency based on the period when two regional agreements, CEFTA and the EUCU, had been in effect. 
H. JOŠIĆ, M. BAŠIĆ: Trade creation and trade diversion effects from Croatia's CEFTA and EU membership EKONOMSKI PREGLED, 72 (4) 489-521 (2021)

\section{CROATIA'S TRADE RELATIONS WITH EU, CEFTA AND REST OF THE WORLD}

Croatia is a small open economy with 15.7 billion US\$ exports and 24.5 billion US\$ imports amounting to a trade deficit of 8.8 billion US\$ in 2017 (WITS, 2019). Exports of goods and services as a share of GDP account for $51.09 \%$, and imports of goods and services form $48.84 \%$ of GDP. Croatia's exports are mainly accounted by exports in services (52.44\%), while imports by goods $(81.0 \%)$. As stated in the introductory section, Croatia's trade growth of 5.13\% in 2017 is larger than the world trade growth of $1.5 \%$, mainly attributed to the growth of the trade in services, tourism (WITS, 2019). Furthermore, its main trading partners in terms of both exports and imports are Germany, Italy, Slovenia and Austria accounting to more than $40 \%$ share in total trade.

Croatia's trade relations with the EU, CEFTA and the rest of world after 2000 are presented and elaborated in this section. Figure 2 shows Croatia's imports, exports and total trade in the period 2000 to 2016 in thousands of USD.

Figure 2.

CROATIA'S IMPORTS, EXPORTS AND TOTAL TRADE, 2000-2016, IN THOUSANDS OF USD

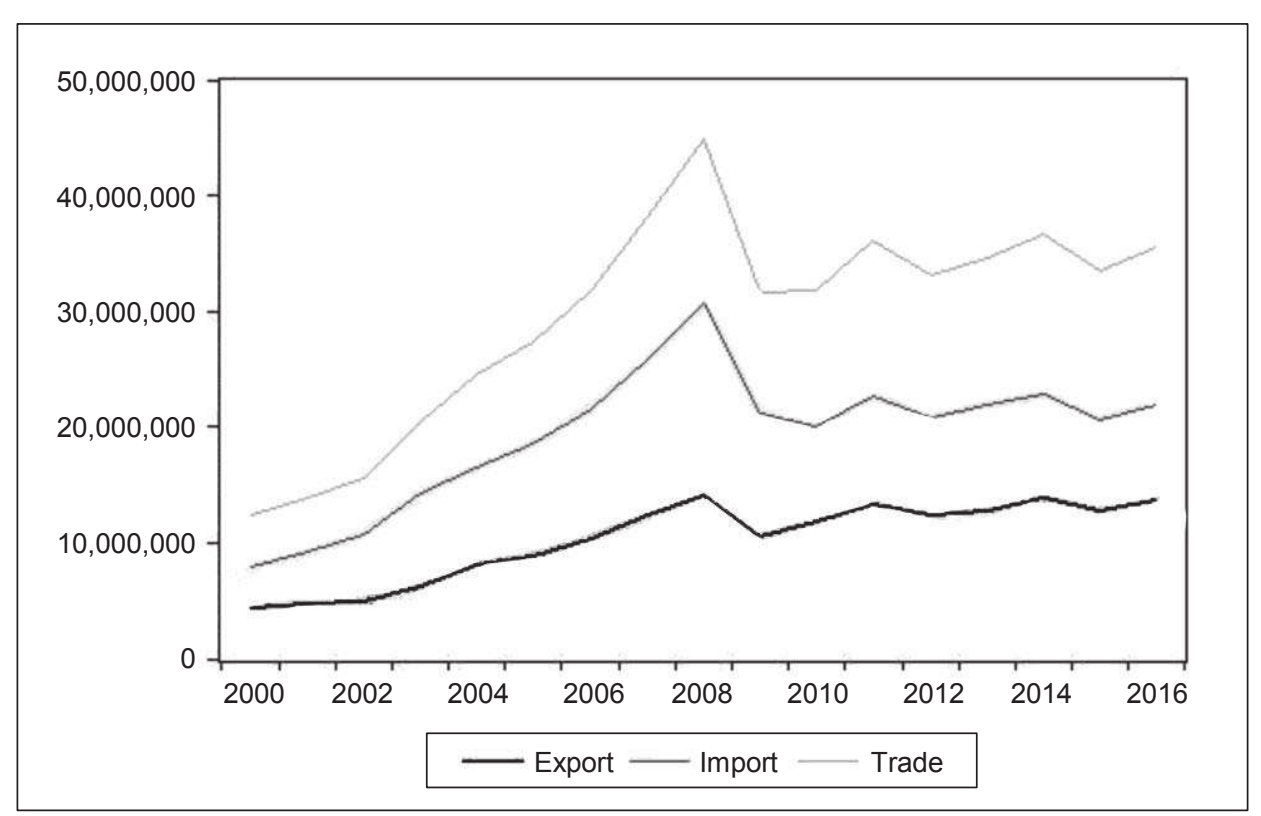

Source: Authors' calculation, WITS 
There is a persistent constant growth of exports, imports and total trade flows up to 2008, after which there was a significant drop in all three variables due to global economic recession. A recovery in trade volumes occurred after 2009. However, trade volumes did not return to those of 2008. Figure 3 shows Croatia's imports, exports and total trade from CEFTA member countries from 2000 to 2016 in thousands of USD.

Figure 3.

\section{CROATIA'S IMPORTS, EXPORTS AND TOTAL TRADE FROM CEFTA, 2000-2016, IN THOUSANDS OF USD}

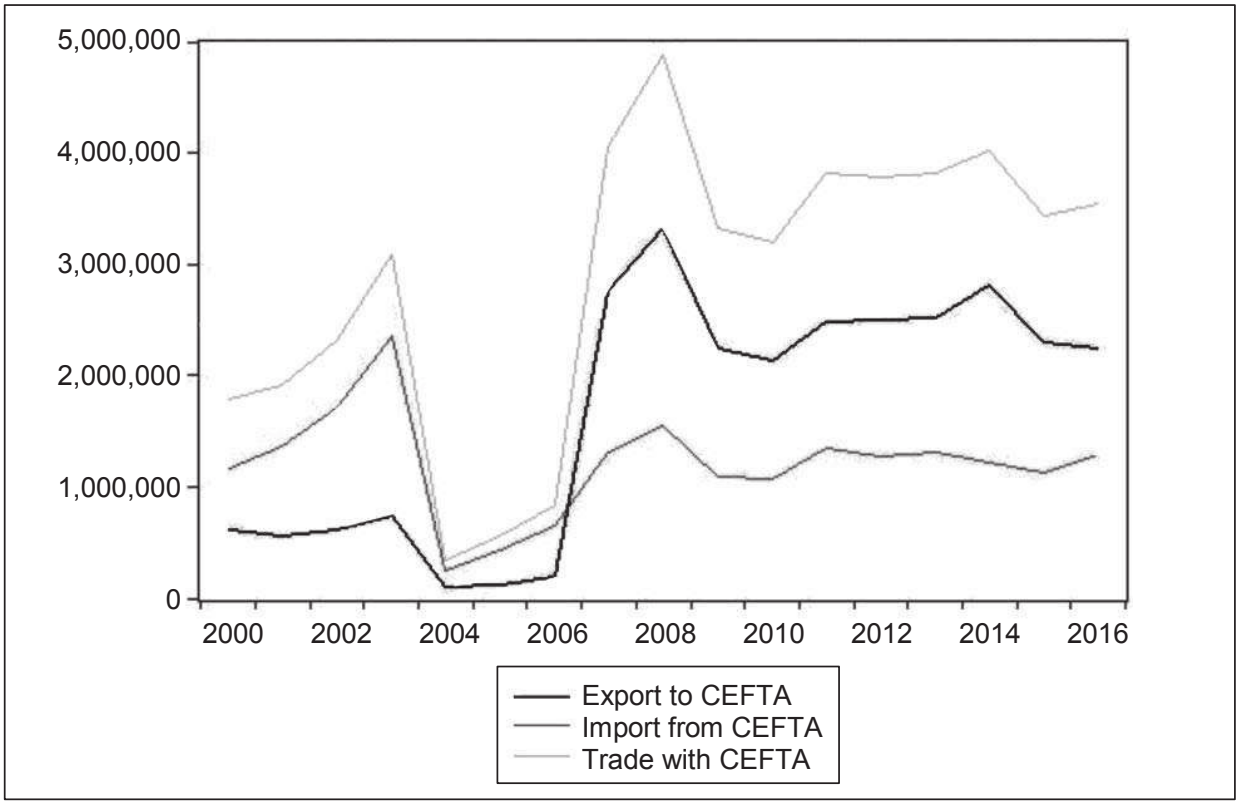

Source: Authors'calculation, WITS

Croatia became a CEFTA member country in 2002. At that time CEFTA already included: the Czech Republic, Slovakia, Hungary, Poland, Slovenia, Bulgaria and Romania. CEFTA and the EU member countries (de)accession dates can be seen in Figure A1 in Appendix. There were three main contractions in CEFTA's trade volumes starting with: (1) 2004 when Czech Republic, Slovakia, Hungary, Poland and Slovenia joined the EU and, therefore, left CEFTA; (2) in 2007 when Bulgaria and Romania joined the EU and left CEFTA; and (3) in 2009 
trade volumes decreased due to a global economic crisis. Croatia's growth in trade volumes from CEFTA membership increased in 2007 as a result of the accession of Albania, Bosnia and Herzegovina, Montenegro, Kosovo, Moldova and Serbia into CEFTA. Croatia left CEFTA in 2013 and joined the EU.

Figure 4 shows Croatia's import, export and total trade with the EU member states.

Figure 4.

CROATIA'S IMPORTS, EXPORTS AND TOTAL TRADE FROM THE EU, 2000-2016

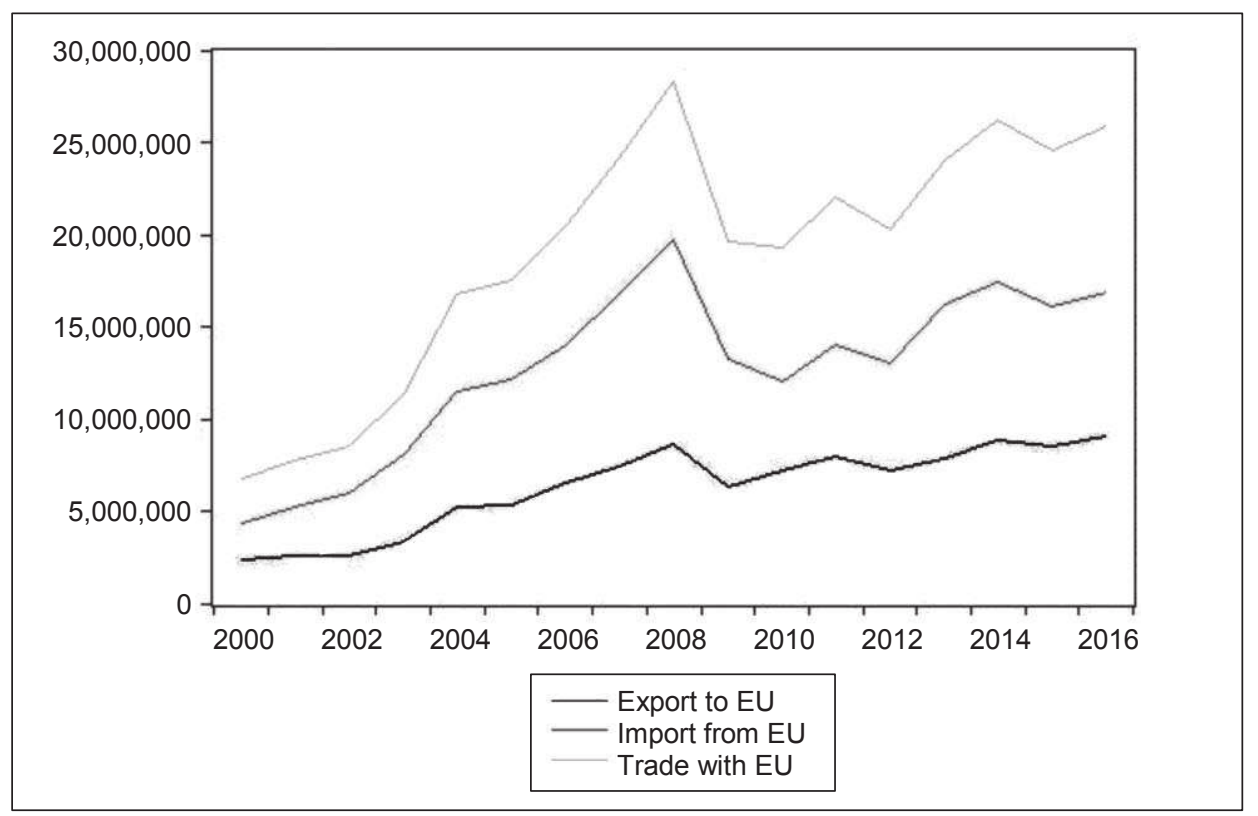

Source: Authors'calculation, WITS

There was a major contraction in trade volumes in 2009 after which trade volumes recovered but did not reach pre-recession volumes of 2008. Croatia's trade volumes with the rest of the world (RoW) countries group (excluding CEFTA and EU countries) also experienced a decline after the global recession (Figure 5). 
Figure 5.

CROATIA'S IMPORTS, EXPORTS AND TOTAL TRADE FROM ROW, 2000-2016

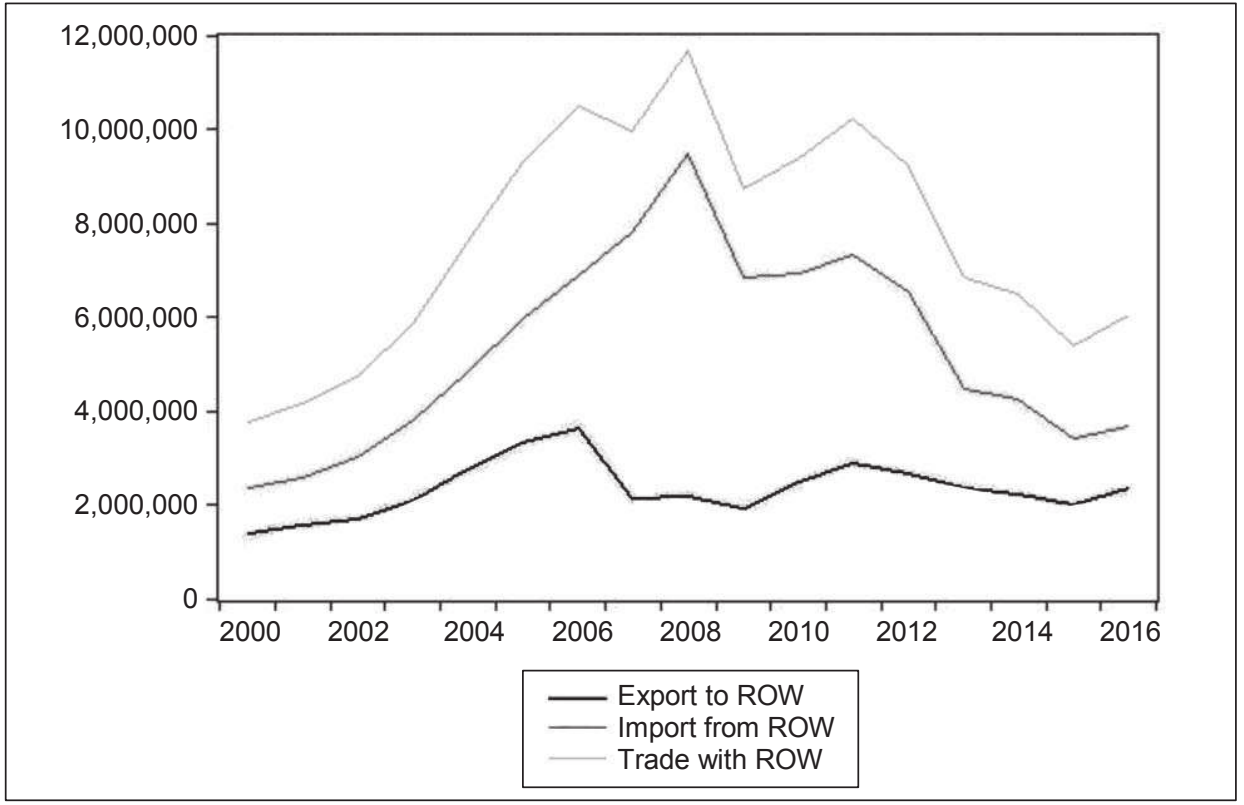

Source: Authors' calculation, WITS

It is meaningful to notice that a decline in trade with the RoW occurs after 2013, i.e. at the time of Croatia's accession into the EU, which points to the existence of a trade diversion effect of Croatia's trade with the RoW (Figure 5). Trade diversion effect occurring with countries from the RoW group can also be seen in Figures 6, 7 and 8, which show the share of export, imports and trade from CEFTA, the EU and RoW in Croatia's total export, total imports and total trade flows. 
H. JOŠIĆ, M. BAŠIĆ: Trade creation and trade diversion effects from Croatia's CEFTA and EU membership EKONOMSKI PREGLED, 72 (4) 489-521 (2021)

Figure 6.

\section{SHARE OF EXPORTS FROM CEFTA, EU AND ROW IN CROATIA'S} TOTAL EXPORTS, 2000-2016

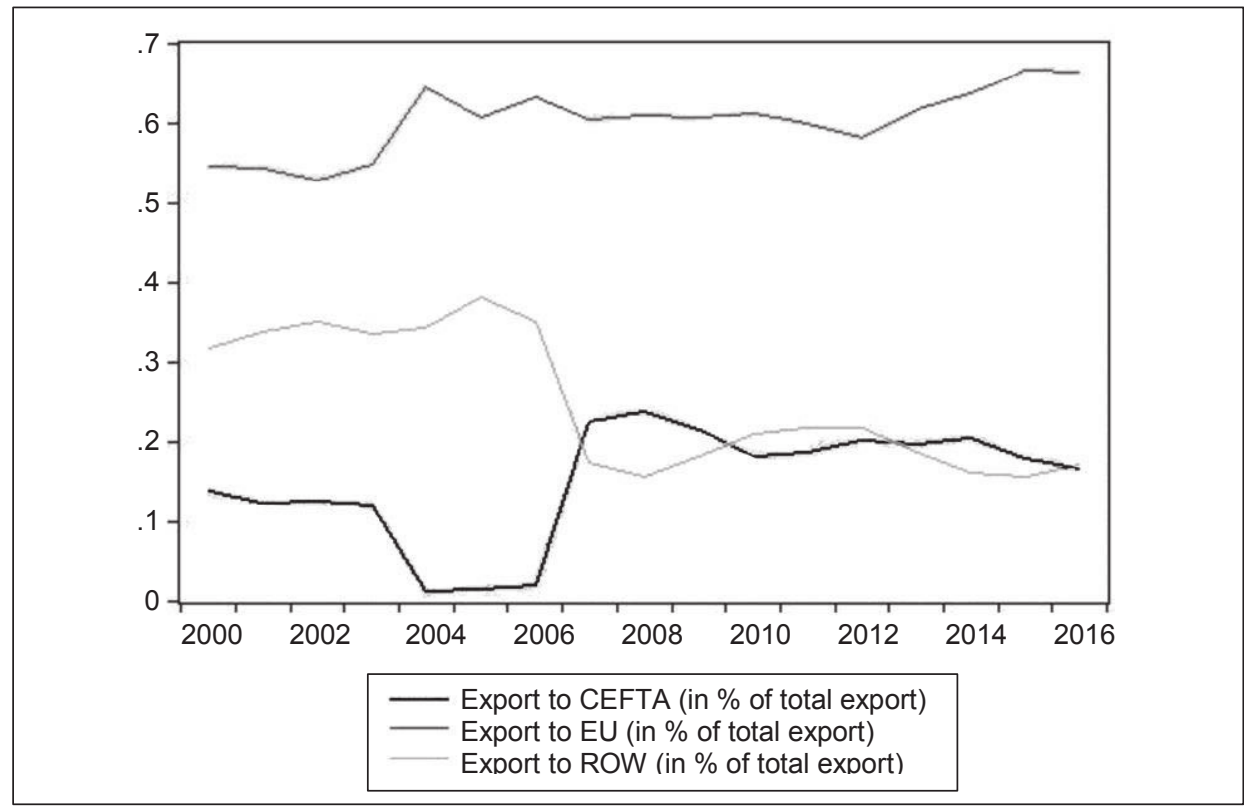

Source: Authors'calculation, WITS

It can be seen that the share of exports to the EU increased from $54.53 \%$ percent in 2000 to $66.35 \%$ of total exports in 2016. Results are in the line with Derado (2008) and Štulec, Vučković and Baković (2014) according to which the exports to the EU amounted at or little above $60 \%$ of total Croatia's exports. On the other side, there was a fall in the share of exports to the RoW group, from $31.65 \%$ in 2000 to $17.18 \%$ in 2016. Similar trend is observed in imports (Figure 7). 
Figure 7.

SHARE OF IMPORTS FROM CEFTA, EU AND ROW IN CROATIA'S

TOTAL IMPORTS, 2000-2016

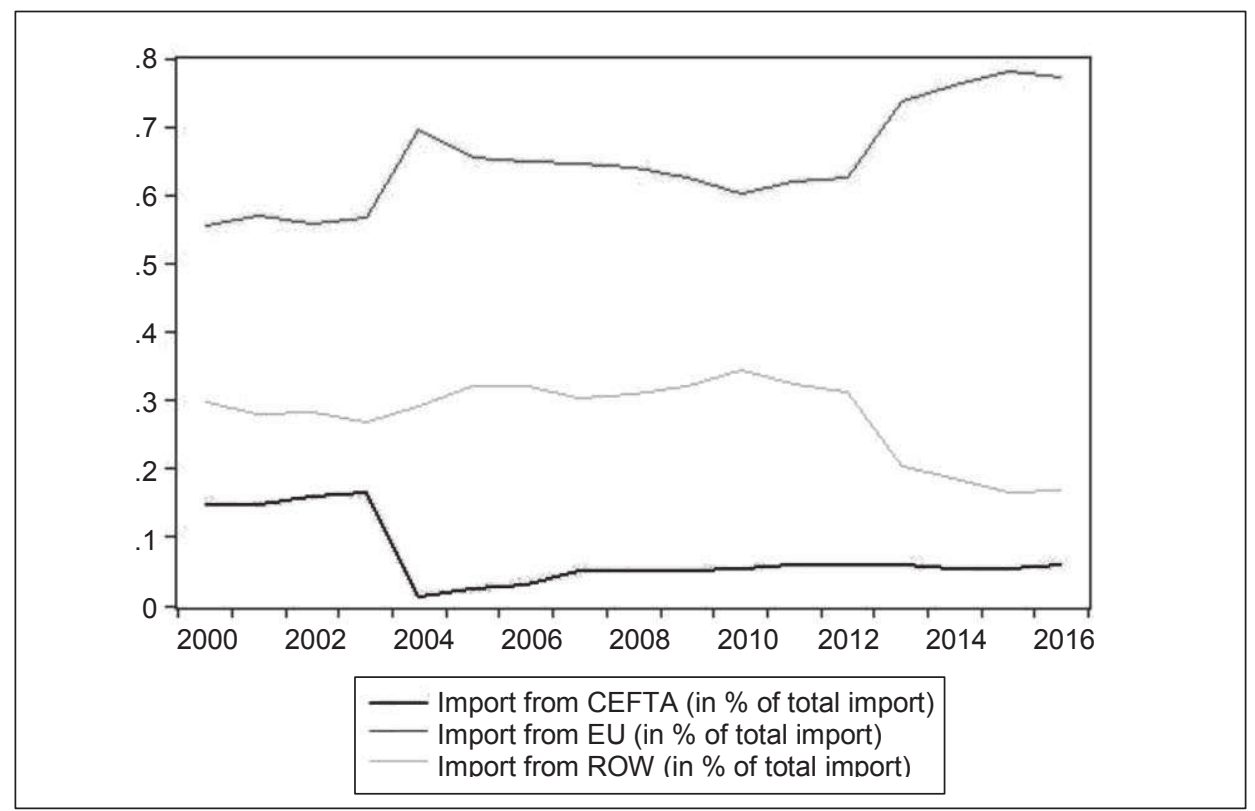

Source: Authors' calculation, WITS

The share of imports from the EU increased and the share of imports from the RoW and CEFTA decreased. The share of imports from the EU significantly increased from $62.55 \%$ in 2012 to $77.20 \%$ in 2016, i.e. after Croatia's accession into the EU in 2013. Although, data indicate that the trade with the RoW was diverted towards the trade with the EU member states, the impact of CEFTA agreement cannot be properly depicted due to (de)accession of countries from the CEFTA to the EU. 
H. JOŠIĆ, M. BAŠIĆ: Trade creation and trade diversion effects from Croatia's CEFTA and EU membership EKONOMSKI PREGLED, 72 (4) 489-521 (2021)

Figure 8 .

SHARE OF TRADE FROM CEFTA, EU AND ROW IN CROATIA'S TOTAL TRADE, 2000-2016

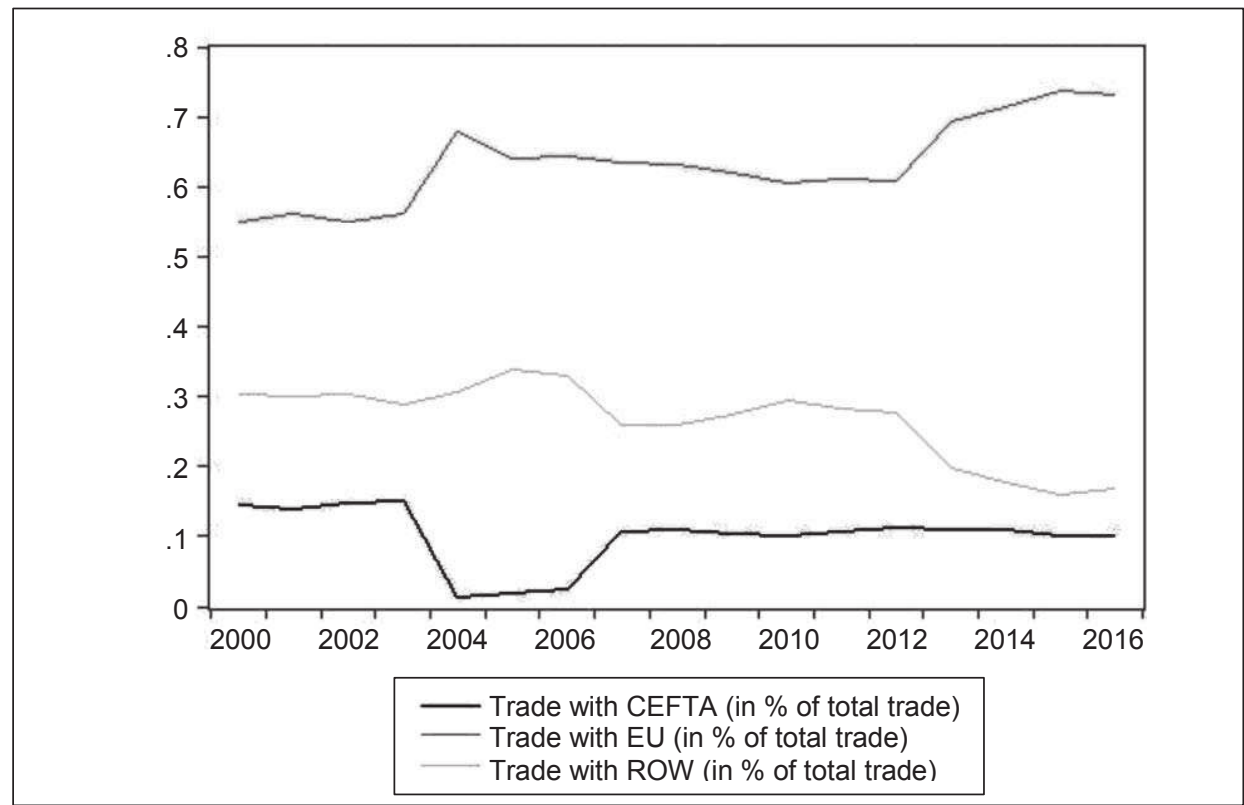

Source: Authors'calculation, WITS

Therefore, Croatia's trade creation and diversion effects from the CEFTA and EU memberships are depicted through the econometric analysis.

Positive trade creation effects were found in the case of Pakistan-China free trade agreement (Uzair and Nawaz, 2018), African economies of ECOWAS (Lugman, Abu Bakar and Izraf, 2016; Deme and Ndrianasy, 2017), East African Community customs union (Buigut, 2016), the Economic and Monetary Community of Central Africa, Southern African Development Community and Southern African Customs Union (Ngepah and Udeagha, 2018), Andean Community and Central American Common Market (Martin Mayoral, Moran Carofiilis and Cajas Guijarro, 2016), ASEAN and China (Yang and Martínez-Zarzoso, 2013; Taguchi, 2015). Trade creation effect exceeds trade diversion in Common Market of the South America (De Boyrie and Kreinin, 2016) and Turkey-EU customs union in particular sectors (Karaman and Ozkale, 2006; Magee, 2016). Although CanadaUnited States Free Trade Agreement (CUSFTA) had predominant trade creation 
effects (Clausing, 2001), NAFTA exhibits mixed effects that are sector- and timedepending (Morais and Bender, 2006; Susanto, Parr Rosson and Adcock, 2007; Martin Mayoral, Moran Carofiilis and Cajas Guijarro, 2016).

\section{METHODOLOGY AND DATA}

This paper uses a gravity model of international trade (Tinbergen, 1962, Anderson \& van Wincoop, 2003) to analyse the welfare effects of trade in regional trade agreements, namely Croatia-CEFTA integration and Croatia-EU integration. Although gravity models lack the ability to separate multilateral and allocation effects, as well as the unobserved omitted variables (Haveman \& Hummels, 1998), a gravity model is a predominant model used to examine the trade creation and trade diversion effects of regional trade integrations (e.g., Esposito, 2017; Urata \& Okabe, 2010; Magee, 2016; Lugman, Abu Bakar \& Izraf, 2016; Deme \& Ndrianasy, 2017; Morais \& Bender, 2006)

Gravity model examines the relationship between economic sizes of countries represented with the variable of gross domestic product (GDP) on one side and distances between the countries on the other side. Trade volumes and GDP exhibit a positive relationship and trade volumes and distance exhibit a negative relationship.

Data for exports, imports and total trade flows for the Republic of Croatia and its trading partners are collected from the World Integrated Trade Solution (WITS) webpage (WITS, 2018). Data on the Republic of Croatia and partner countries' GDP are obtained from the World Bank's database (World Bank, 2018). GDP is expressed in constant 2010 US\$. Data on distances between Croatia's capital city Zagreb and other trading countries' capital cities are provided from DistanceFromTo webpage (DistanceFromTo, 2018).

Gravity model of bilateral trade is given in Equation 1:

$$
T_{i j}=\alpha \frac{G D P_{i} G D P_{j}}{D_{i j}}
$$

where $T_{i j}$ is a measure of bilateral trade flows (import, export or total trade), $\alpha$ is a constant, $G D P_{i}$ and $G D P_{j}$ represent gross domestic product of country $i$ (Croatia) and country $j$ (trade partner country) in constant 2010 US\$. $D_{i j}$ is geographical distance between countries $i$ and $j$. Geographical distance between the two country's capital cities is approximated as an air distance between capital cities. The gravity model states that trade flows increase with an increase in GDP values of a partner country and decrease as distances between capital cities increase. There 
are six dummy variables in our model: (1) trade creation from CEFTA dummy (TCCD), (2) trade diversion from CEFTA dummy (TDCD), (3) trade creation from the EU dummy (TCEUD), (4) trade diversion from the EU dummy (TDEUD), (5) financial crisis dummy and (6) preferential trade agreements (PTA) dummy. Trade creation dummy variables take value of 1 when both countries are members of an economic integration (for TCCD it is CEFTA, and for TCEUD it is the EU) and trade diversion dummy variables take value 1 only if Croatia is a member of an economic integration and another country is not. A positive and significant coefficient of trade creation dummy indicates that trade between members countries of the trade agreement is growing more than trade with countries outside of the agreement (Mitaj \& Osmani, 2017). In order to account for deflation of trade flows our model considers time dummies (e.g., financial crisis dummy). Financial crisis dummy takes a value of 1 to account for the spillover effects of a global financial crisis and 0 in other years. The Republic of Croatia was in a recession between 2009 and 2014, which was caused by a spillover effect from the global financial crisis. Preferential trade agreements (PTA) dummy takes the value 1 for countries with whom Croatia has had preferential trade agreements, and 0 otherwise. Croatia has had preferential trade agreements with 39 countries including EU-27, EFTA, CEFTA and Turkey. CEFTA and the EU have been excluded as a PTA dummy variable as they are analysed and included as a trade creation or trade diversion dummy variable. Moreover, the analysis includes the variable remoteness to obtain unbiased estimates of the impact of distance on imports, exports and total trade flows, i.e., to control for the multilateral resistance terms for importing and exporting countries (Anderson \& van Wincoop, 2004). It is measured as a country's average weighted distance from its trading partners in which weights are the partner countries' share in the world GDP (Head, 2003).

The gravity model is obtained through several models: (1) a linear model in which no trade between countries is represented with value 1 as a minimal value, (2) a robust non-linear model tackling the heteroskedasticity problem with the (Pseudo) Poisson maximum likelihood (ML) estimator (PPML) that disregards the zero values (Santos Silva \& Tenreyro, 2006; Westerlund \& Wilhelmsson, 2011), and (3) a Tobit estimator with left-censoring at zero on the log of trade wherein is a possibility of biasness as a 'desired' negative trade due to small values of trade being rounded to zero. Zero flows of trade represent a methodological challenge for econometric analysis since the natural logarithm of zero is unidentified. Some economists approach this problem by ignoring the missing observations, some substitute arbitrary small numbers for the zeroes and others use a Tobit model if trade values are bounded by zero from below (Gauto, 2012). As stated, the main problem with omission of the zero trade values is that results in that case can be biased. The extended form of the gravity model is constructed for imports, exports and total trade flows and as such given in Equations 2-4. 
$\log$ Imports $_{\mathrm{ijt}}=\alpha+\beta_{1} \log$ GDP $_{\mathrm{jt}}+\beta_{2} \log$ DISTANCE $_{\mathrm{ijt}}+\beta_{3} \log$ REMOTENESS $_{\mathrm{ijt}}+$

$$
\begin{gathered}
\beta_{4} \text { PTA }_{\mathrm{ijt}}+\beta_{5} \text { FINANCIAL CRISIS }_{\mathrm{ijt}}+\beta_{6} \text { TCCD }_{\mathrm{ijt}}+\beta_{7} \text { TDCD }_{\mathrm{ijt}}+\beta_{8} \text { TCEUD }_{\mathrm{ijt}}+ \\
\beta_{9} \text { TDEUD }_{\mathrm{ijt}}+\varepsilon_{\mathrm{i}, \mathrm{t}}
\end{gathered}
$$

$\log$ Exports $_{\mathrm{ijt}}=\alpha+\beta_{1} \log \mathrm{GDP}_{\mathrm{jt}}+\beta_{2} \log$ DISTANCE $_{\mathrm{ijt}}+\beta_{3} \log$ REMOTENESS $_{\mathrm{ijt}}+$

$$
\begin{gathered}
\beta_{4} \text { PTA }_{\mathrm{ijt}}+\beta_{5} \text { FINANCIAL CRISIS }_{\mathrm{ijt}}+\beta_{6} \text { TCCD }_{\mathrm{ijt}}+\beta_{7} \text { TDCD }_{\mathrm{ijt}}+\beta_{8} \text { TCEUD }_{\mathrm{ijt}}+ \\
\beta_{9} \text { TDEUD }_{\mathrm{ijt}}+\varepsilon_{\mathrm{i}, \mathrm{t}}
\end{gathered}
$$

$\log$ Total_trade $_{\mathrm{ijt}}=\alpha+\beta_{1} \log \mathrm{GDP}_{\mathrm{jt}}+\beta_{2} \log$ DISTANCE $_{\mathrm{ijt}}+\beta_{3} \log$ REMOTENESS $_{\mathrm{ijt}}+$

$$
\begin{gathered}
\beta_{4} \text { PTA }_{\mathrm{ijt}}+\beta_{5} \text { FINANCIAL CRISIS }_{\mathrm{ijt}}+\beta_{6} \text { TCCD }_{\mathrm{ijt}}+\beta_{7} \text { TDCD }_{\mathrm{ijt}}+\beta_{8} \text { TCEUD }_{\mathrm{ijt}}+ \\
\beta_{9} \text { TDEUD }_{\mathrm{ijt}}+\varepsilon_{\mathrm{i}, \mathrm{t}}
\end{gathered}
$$

Data is obtained for the period between 2000 and 2016, and includes the Republic of Croatia's trade with 180 partner countries. A cross-country panel regression analysis of imports, export and total trade flows is estimated using pooled OLS (POLS), fixed effects (FE), random effects (RE), PPML and a Tobit model. Basic pooled OLS regression model is presented in Equation 5.

$$
\log y_{i, t}=\beta_{1}+\beta_{2} \log x_{i, t, 2}+\cdots+\beta_{k} \log x_{i, t, k}+\varepsilon_{i, t}
$$

where $\mathrm{y}_{\mathrm{i}}$ is a dependent variable, $\mathrm{x}_{\mathrm{i}}$ is a independent variable, $\beta$ is a constant, $\beta_{1}$ is a regression coefficient, $i, t$ are indices for individuals and time and $\varepsilon$ is an error term. Assumptions of the pooled model are error terms that are independently and identically distributed with expected value 0 and a constant variance. Fixed effects model is given in Equation 6.

$$
\log y_{\mathrm{i}, \mathrm{t}}=\beta_{1}+\gamma_{1} \sum_{\mathrm{i}=1}^{\mathrm{N}-1} \text { Dummy }_{\mathrm{i}}+\beta_{2} \log \mathrm{x}_{\mathrm{i}, \mathrm{t}, 2}+\beta_{\mathrm{kl}} \log \mathrm{x}_{\mathrm{i}, \mathrm{t}, \mathrm{k}}+\mu_{\mathrm{i}, \mathrm{t}}
$$

and random effects model is given in Equations 7 to 10:

$$
\begin{aligned}
\log y_{i, t}= & \beta_{1 i}+\beta_{2} \log x_{i, t, 2}+\cdots+\beta_{k} \log x_{i, t, k}+\mu_{i, t} \\
& \beta_{1 i}=\beta_{1}+\varepsilon_{i} \\
\log y_{i, t}= & \beta_{1}+\beta_{2} \log x_{i, t, 2}+\cdots+\beta_{k} \log x_{i, t, k}+\varepsilon_{i, t}+\mu_{i, t} \\
\log y_{i, t}= & \beta_{1}+\beta_{2} x_{i, t, 2}+\cdots+\beta_{k} x_{i, t, k}+\omega_{i, t}
\end{aligned}
$$


In order to differentiate between fixed effects and random effects model, we use Hausman test, and F-test to compare fixed effects model and pooled OLS. As previously mentioned, gravity model is often estimated using a log-linearized form. A shortcoming of this estimation approach relates to cases in which $F_{i j t}$ is equal to zero, which can lead to significant biases and extremely high values for the regression coefficients. Hence, we assigned arbitrarily value of 1 for exports, imports and trade flows to mitigate this problem. Additionally, to account for this shortcoming, the Poisson Pseudo Maximum Likelihood estimator (PPML) is also used (Santos Silva \& Tenreyro, 2006, 2011), as given in Equation 11.

$$
\begin{array}{r}
\mathrm{F}_{\mathrm{ijt}}=\exp \left[\alpha+\beta_{1} \log \left(\mathrm{GDP}_{\mathrm{jt}}\right)+\beta_{2} \log \left(\operatorname{DISTANCE}_{\mathrm{ijt}}\right)+\beta_{3} \log \left(\operatorname{REMOTENESS}_{\mathrm{ijt}}\right)+\right. \\
\left.\beta_{4} \mathrm{PTA}_{\mathrm{ijt}}+\beta_{5} \text { FIN_CRISIS }_{\mathrm{ijt}}+\beta_{6} \mathrm{TCCD}_{\mathrm{ijt}}+\beta_{7} \text { TDCD }_{\mathrm{ijt}}+\beta_{8} \text { TCEUD }_{\mathrm{ijt}}+\beta_{9} \text { TDEUD }_{\mathrm{ijt}}\right] \varepsilon_{\mathrm{ijt}}
\end{array}
$$

The censored Tobit model (Tobin, 1958) is often employed to analyse datasets in which a substantial fraction of the observations is equal to zero. The Tobit model represents a situation in which part of the observations on the dependant variable is left censored (Linders \& de Groot, 2006). In this paper both PPML and Tobit model are used to estimate trade effects from Croatia's CEFTA and EU membership using the presented equations.

Proper specification of the gravity model requires controlling for multilateral resistance terms (MRT) (Adam \& Cobham, 2007), accounting for trade resistance between countries, i.e., bilateral trade flows between trading partners and dependent on all other trading partners of these two countries (Anderson \& van Wincoop, 2003). In our analysis, MRT is controlled in POLS, RE, PPML and Tobit estimations using the variable remoteness. Remoteness measures country's average weighted distance from its trading partner countries. Remoteness variable is calculated using Equations 12.

$$
\operatorname{Rem}_{i}=\sum_{j} \frac{\operatorname{dist}_{i j}}{G D P_{j} G D P_{w}}
$$

where weights are the partner countries' shares of the world GDP $\left(G D P_{w}\right)$.

Unbiased estimates of trade creation (TC) and trade diversion (TD) effects of CEFTA and the EU membership require a control of other free trade agreements (FTA), which Croatia had enforced during the period 2000-2016, i.e., FTAs before the EU accession (including the Stability and Association agreement with the EU), and European FTAs since the EU membership. The Republic of Croatia currently has preferential trade agreements (PTAs) signed with 39 countries (EU27, 7 CEFTA countries, 4 EFTA countries and Turkey) (International Trade Centre, 2019). PTA dummy variable is used to control for the effects of other existing 
FTAs during the observed period. PTA dummy variable obtains value 1 when Croatia has had a PTA with a particular country in the observed period and value 0 if it has had not. PTAs with CEFTA and the EU are left out of the PTA dummy variable as they are part of the trade creation dummies.

In order to control for the common annual-specific shocks we use Financial crisis dummy variable. Namely, a negative impact of the global financial crisis is evident in 2009 Croatian trade flows (Figure 2) encompassing a significant decrease of imports, exports and total trade flows until 2014. The Financial crisis dummy is used for the period 2009-2014 when Croatia was is a recession resulting from a global financial crisis.

\section{RESULTS OF ECONOMETRIC ANALYSIS AND DISCUSSION}

Table 1 shows descriptive statistics of variables used in the regression analyses. Dependent variables are imports, exports and total trade flows, while the models' independent variables are real value of gross domestic product, distance, remoteness and the dummy variables related to trade creation and trade diversion effects, as well as the dummy variables PTA and financial crisis, as explained in Section 5. 
Table 1.

DESCRIPTIVE STATISTICS OF VARIABLES

\begin{tabular}{|c|c|c|c|c|c|c|c|c|c|c|c|c|}
\hline & IMPORTS & EXPORTS & TRADE & GDP & DISTANCE & REMOTENESS & PTA & FIN. CRISIS & TCCD & TDCD & TCEUD & TDEUD \\
\hline Mean & $1.05 \mathrm{E}+08$ & $55,823,322$ & $1.61 E+08$ & $3.44 \mathrm{E}+11$ & $5,987.723$ & $3.79 \mathrm{E}+08$ & 0.022099 & 0.352941 & 0.020474 & 0.625284 & 0.035099 & 0.200195 \\
\hline Maximum & $5.26 \mathrm{E}+09$ & $2.69 \mathrm{E}+09$ & $7.95 \mathrm{E}+09$ & $1.70 \mathrm{E}+13$ & $18,259.9$ & $3.26 \mathrm{E}+10$ & 1 & 1 & 1 & 1 & 1 & 1 \\
\hline Std. Dev. & $3.90 \mathrm{E}+08$ & $2.20 \mathrm{E}+08$ & $5.87 \mathrm{E}+08$ & $1.32 \mathrm{E}+12$ & 4094.322 & $2.32 \mathrm{E}+09$ & 0.147031 & 0.477962 & 0.14164 & 0.484128 & 0.18406 & 0.400211 \\
\hline Skewness & 6.45496 & 6.602995 & 6.479640 & 8.402567 & 0.616241 & 11.57579 & 6.501738 & 0.615457 & 6.772162 & -0.517651 & 5.052437 & 1.498477 \\
\hline Kurtosis & 52.628 & 52.78106 & 53.36740 & 87.09531 & 2.990336 & 147.0921 & 43.27260 & 1.378788 & 46.86217 & 1.267963 & 26.52712 & 3.245435 \\
\hline Sum & $3.22 \mathrm{E}+11$ & $1.72 \mathrm{E}+11$ & $4.94 \mathrm{E}+11$ & $1.06 \mathrm{E}+15$ & 18322431 & $1.16 \mathrm{E}+12$ & 68.0 & 1086.0 & 63.0 & $1,924.0$ & 108.0 & 616.0 \\
\hline Sum Sq. Dev. & $4.67 \mathrm{E}+20$ & $1.49 \mathrm{E}+20$ & $1.06 \mathrm{E}+21$ & $5.35 \mathrm{E}+27$ & $5.13 \mathrm{E}+10$ & $1.65 \mathrm{E}+22$ & 66.49724 & 702.7059 & 61.71011 & 720.9529 & 104.2093 & 492.6799 \\
\hline Observations & 3,077 & 3,077 & 3,077 & 3,077 & 3,060 & 3,060 & 3,077 & 3,077 & 3,077 & 3,077 & 3,077 & 3,077 \\
\hline
\end{tabular}

Source: Authors' calculations 
Table 2 depicts results of the cross-country panel regression analysis for Croatian imports in the period from 2000 to 2016 using POLS, FE, RE models and those using PPML and Tobit estimators. There are 3,043 observations in POLS, FE, PPML and Tobit model and 3,077 in the robust PPML model.

Table 2.

CROSS-COUNTRY PANEL REGRESSION FOR CROATIA'S IMPORTS, 2000-2016

\begin{tabular}{|c|c|c|c|c|c|}
\hline Dependent variable & \multicolumn{5}{|c|}{ (log) Imports } \\
\hline Indep. variable/Model & POLS & $\mathrm{FE}$ & $\mathbf{R E}$ & PPML & Tobit \\
\hline Constant & $\begin{array}{c}-84.37399 * * * \\
(26.37253) \\
\end{array}$ & $\begin{array}{c}-30.44303 * * * \\
(6.869613) \\
\end{array}$ & $\begin{array}{c}-82.81402 * * * \\
(19.48989) \\
\end{array}$ & $\begin{array}{c}-63.84820 * * * \\
(0.000785) \\
\end{array}$ & $\begin{array}{c}-92.02241^{* * * *} * \\
(29.04897)\end{array}$ \\
\hline $\log$ GDP & $\begin{array}{c}3.749877 * * * \\
(0.833885)\end{array}$ & $\begin{array}{c}1.789008^{* * * *} \\
(0.288716)\end{array}$ & $\begin{array}{c}3.729581 * * * \\
(0.614529)\end{array}$ & $\begin{array}{c}3.013261 * * * \\
(2.48 \mathrm{E}-05)\end{array}$ & $\begin{array}{c}4.011449 * * * \\
(0.918542)\end{array}$ \\
\hline log Distance & $\begin{array}{c}-3.327040 * * * \\
(0.837841)\end{array}$ & & $\begin{array}{c}-3.457510^{* * * *} \\
(0.653896) \\
\end{array}$ & $\begin{array}{c}-3.429016 * * * \\
(2.48 \mathrm{E}-05) \\
\end{array}$ & $\begin{array}{c}-3.530169^{* * *} * \\
(0.922790)\end{array}$ \\
\hline log Remoteness & $\begin{array}{c}2.164348 * * * \\
(0.834535)\end{array}$ & & $\begin{array}{c}2.164828 * * * \\
(0.621713)\end{array}$ & $\begin{array}{c}2.214921 * * * \\
(2.47 \mathrm{E}-05)\end{array}$ & $\begin{array}{l}2.346594 * * \\
(0.919192)\end{array}$ \\
\hline PTA & $\begin{array}{c}0.761214 \\
(0.413648)\end{array}$ & & $\begin{array}{c}0.605035 \\
(1.166750)\end{array}$ & $\begin{array}{c}-0.782186 * * * \\
(1.03 \mathrm{E}-05)\end{array}$ & $\begin{array}{c}0.727210 \\
(0.451622)\end{array}$ \\
\hline Financial crisis & $\begin{array}{c}-0.157683 \\
(0.151985) \\
\end{array}$ & $\begin{array}{c}-0.035727 \\
(0.108819) \\
\end{array}$ & $\begin{array}{l}-0.154307 \\
(0.111891) \\
\end{array}$ & $\begin{array}{c}-0.174462 * * * \\
(4.30 \mathrm{E}-06) \\
\end{array}$ & $\begin{array}{c}-0.171331 \\
(0.167320) \\
\end{array}$ \\
\hline TCCD & $\begin{array}{c}3.546863 * * * \\
(0.469377)\end{array}$ & $\begin{array}{c}1.579383 * * * \\
(0.395599)\end{array}$ & $\begin{array}{c}1.606991 * * * \\
(0.389092)\end{array}$ & $\begin{array}{c}0.857888 * * * \\
(9.93 \mathrm{E}-06)\end{array}$ & $\begin{array}{c}3.674476 * * * \\
(0.512969)\end{array}$ \\
\hline TDCD & $\begin{array}{c}0.491242^{* * *} * \\
(0.177071) \\
\end{array}$ & $\begin{array}{c}0.721606 \\
(0.122650) \\
\end{array}$ & $\begin{array}{c}0.565842^{* * *} * \\
(0.130765) \\
\end{array}$ & $\begin{array}{c}0.313551^{* * *} \\
(5.70 \mathrm{E}-06) \\
\end{array}$ & $\begin{array}{c}0.549368 * * * \\
(0.195128) \\
\end{array}$ \\
\hline TCEUD & $\begin{array}{c}0.494380 \\
(0.418917)\end{array}$ & $\begin{array}{c}0.566317 \\
(0.284529)\end{array}$ & $\begin{array}{c}0.075281 \\
(0.320653)\end{array}$ & $\begin{array}{c}-0.162258^{* * *} * \\
(8.09 \mathrm{E}-06)\end{array}$ & $\begin{array}{c}0.381211 \\
(0.458767)\end{array}$ \\
\hline TDEUD & $\begin{array}{c}-2.653550 * * * \\
(0.286056)\end{array}$ & $\begin{array}{c}-2.094420 * * * \\
(0.173827)\end{array}$ & $\begin{array}{c}-2.565325^{* * * *} \\
(0.211184)\end{array}$ & $\begin{array}{c}-0.232133 * * * \\
(1.05 \mathrm{E}-05)\end{array}$ & $\begin{array}{c}-2.907818 * * * \\
(0.315361)\end{array}$ \\
\hline Adjusted R-squared & 0.666839 & 0.814515 & 0.278270 & & \\
\hline S.E. of regression & 3.295078 & 2.454947 & 2.430249 & & 3.292144 \\
\hline Prob. (F-statistic) & 0.00000 & 0.00000 & 0.00000 & & \\
\hline Mean dependent variable & 12.59241 & 12.57780 & 3.264383 & $1.06 \mathrm{E}+08$ & 12.59241 \\
\hline S.D. dependent variable & 5.708719 & 5.700166 & 2.860642 & $3.92 \mathrm{E}+08$ & 5.708719 \\
\hline Pearson SSR & & & & $2.88 \mathrm{E}+11$ & \\
\hline Quasi-log likelihood & & & & $6.23 \mathrm{E}+12$ & \\
\hline Akaike info criterion & 5.226018 & 4.692936 & & & 5.138488 \\
\hline Durbin -Watson & 0.645435 & 1.237828 & 1.173904 & & \\
\hline Observations & 3,043 & 3,077 & 3,043 & 3,043 & 3,043 \\
\hline Hausman test & & Chi-Sq. Sta & stic $(0.0000), \mathrm{P}_{1}$ & b. $(1.0000)$ & \\
\hline Loglikelihood test & Cross-se & tion F (Prob. 0.0 & 0), Cross-sectio & Chi-square (Prot & $0.0000)$ \\
\hline
\end{tabular}

Note: Standard errors in parentheses. Statistical significance: $*<0.10 ; * *<0.05 ; * * *<0.01$.

Source: Authors' calculations 
Results of Hausman test show that random effects model is more appropriate than fixed effects model. Independent variables such as GDP and distance were significant under $1 \%$ significance level. There is a positive effect of country's GDP on imports and a negative effect of distance between partner countries and the value of imports. These results were expected.

Moreover, remoteness is positive and significant in all models, while PTA dummy is negative and significant only in the PPML model. Financial crisis dummy is significant only in a robust PPML estimator model.

Trade creation in imports from CEFTA (TCCD dummy) is significant under $1 \%$ significance level in all models. Trade creation in imports from the EU membership (TCEUD) is only significant in the PPML model where it is negative implying a decrease in imports from the EU. Croatia had an increase in imports from CEFTA during CEFTA membership, and a decrease in imports from the EU during the EU membership.

Trade diversion in imports from CEFTA (TDCD dummy) is significant and positive under $1 \%$ significance level in all models apart from the FE model, while trade diversion in imports from the EU (TDEUD dummy) is significant and negative under $1 \%$ significance level in all estimated models. Croatia had an increase in imports from RoW during CEFTA membership and a decrease in imports from RoW during the EU membership.

In terms of imports and the CEFTA membership, in all estimated models under $1 \%$ significance level the effect of trade creation is larger than trade diversion in the period 2000-2016 (TCCD > TDCD) from CEFTA membership. Hence, a trade creation in imports from CEFTA membership is present. Membership in CEFTA resulted in an increase in imports from other CEFTA countries more than from the ROW.

In terms of imports and the EU membership, there is a positive nonsignificant effect of trade creation and a negative significant effect of trade diversion in the period 2000-2016. During the EU membership there had been an (nonsignificant) increase in imports from the EU member states, and a significant decrease in imports from the RoW. The dummy coefficients are greater for trade diversion than trade creation (TDEUD > TCEUD), signalling trade has fallen more with RoW during the EU membership than with the EU, and implying a trade creation in imports with the EU member states during the EU membership.

Table 3 shows the results of a cross-country panel regression for Croatian exports in the observed period, 2000-2016. 
Table 3.

\section{CROSS-COUNTRY PANEL REGRESSION FOR CROATIA'S EXPORTS, 2000-2016}

\begin{tabular}{|c|c|c|c|c|c|}
\hline Dependent variable & \multicolumn{5}{|c|}{ (log) Exports } \\
\hline Indep. variable/Model & POLS & FE & RE & PPML & Tobit \\
\hline Constant & $\begin{array}{c}-147.4754 * * * \\
(33.11403)\end{array}$ & $\begin{array}{c}-77.77430 * * * \\
(8.780441)\end{array}$ & $\begin{array}{c}-144.6053 * * * * \\
(25.19927)\end{array}$ & $\begin{array}{c}-81.56500 * * * \\
(0.001079)\end{array}$ & $\begin{array}{c}-162.6967 * * * \\
(39.69062)\end{array}$ \\
\hline $\log$ GDP & $\begin{array}{c}5.926406^{* * * *} \\
(1.047047)\end{array}$ & $\begin{array}{c}3.713692 * * * \\
(0.369024)\end{array}$ & $\begin{array}{c}5.851315^{* * * *} \\
(0.794714)\end{array}$ & $\begin{array}{c}3.555598^{* * * *} \\
(3.41 \mathrm{E}-05)\end{array}$ & $\begin{array}{c}6.486022 * * * \\
(1.254971)\end{array}$ \\
\hline log Distance & $\begin{array}{c}-6.629793 * * * \\
(1.052014)\end{array}$ & & $\begin{array}{c}-6.534063 * * * * \\
(0.842217)\end{array}$ & $\begin{array}{c}-4.397567 * * * \\
(3.42 \mathrm{E}-05)\end{array}$ & $\begin{array}{c}-7.157663 * * * * \\
(1.260810)\end{array}$ \\
\hline $\log$ Remoteness & $\begin{array}{c}4.479738 * * * \\
(1.047864)\end{array}$ & & $\begin{array}{c}4.362662 * * * \\
(0.803376)\end{array}$ & $\begin{array}{c}2.999311 * * * * \\
(3.40 \mathrm{E}-05)\end{array}$ & $\begin{array}{c}4.831228 * * * \\
(1.255899)\end{array}$ \\
\hline PTA & $\begin{array}{l}-0.271670 \\
(0.519387)\end{array}$ & & $\begin{array}{c}-0.409373 \\
(1.454989)\end{array}$ & $\begin{array}{c}-1.167084 * * * \\
(1.62 \mathrm{E}-05)\end{array}$ & $\begin{array}{l}-0.459547 \\
(0.613435)\end{array}$ \\
\hline Financial crisis & $\begin{array}{c}0.197252 \\
(0.190837)\end{array}$ & $\begin{array}{l}0.262583 * \\
(0.139088)\end{array}$ & $\begin{array}{c}0.195768 \\
(0.144706)\end{array}$ & $\begin{array}{c}-0.061141 * * * \\
(5.83 \mathrm{E}-06)\end{array}$ & $\begin{array}{c}0.257161 \\
(0.228837)\end{array}$ \\
\hline TCCD & $\begin{array}{c}2.285760 * * * \\
(0.589362)\end{array}$ & $\begin{array}{l}1.112585 * * \\
(0.505638)\end{array}$ & $\begin{array}{l}1.152107 * * \\
(0.502822)\end{array}$ & $\begin{array}{c}0.901289^{* * * *} \\
(1.02 \mathrm{E}-05)\end{array}$ & $\begin{array}{c}2.434152 * * * \\
(0.697162)\end{array}$ \\
\hline TDCD & $\begin{array}{c}0.017202 \\
(0.222335)\end{array}$ & $\begin{array}{c}0.221153 \\
(0.156766)\end{array}$ & $\begin{array}{c}0.080742 \\
(0.169113)\end{array}$ & $\begin{array}{c}0.052550^{* * * *} \\
(7.97 \mathrm{E}-06)\end{array}$ & $\begin{array}{c}0.074494 \\
(0.267063)\end{array}$ \\
\hline TCEUD & $\begin{array}{l}-0.432399 \\
(0.526003)\end{array}$ & $\begin{array}{c}0.396531 \\
(0.363673)\end{array}$ & $\begin{array}{l}-0.376628 \\
(0.414576)\end{array}$ & $\begin{array}{c}-0.412794 * * * \\
(1.13 \mathrm{E}-05)\end{array}$ & $\begin{array}{l}-0.727945 \\
(0.624012)\end{array}$ \\
\hline TDEUD & $\begin{array}{l}-0.163322 \\
(0.359180)\end{array}$ & $\begin{array}{c}0.172887 \\
(0.222178)\end{array}$ & $\begin{array}{l}-0.140316 \\
(0.273117)\end{array}$ & $\begin{array}{c}0.218688 * * * \\
(1.26 \mathrm{E}-05)\end{array}$ & $\begin{array}{l}-0.021233 \\
(0.429303)\end{array}$ \\
\hline Adjusted R-squared & 0.572465 & 0.755529 & 0.199751 & & \\
\hline S.E. of regression & 4.137385 & 3.137807 & 3.141500 & & 4.144312 \\
\hline Prob. (F-statistic) & 0.00000 & 0.00000 & 0.00000 & & \\
\hline Mean dependent variable & 11.73046 & 11.68383 & 3.153864 . & 56438487 & 11.73046 \\
\hline S.D. dependent variable & 6.327613 & 6.346178 & 3.511758 & $2.21 \mathrm{E}+08$ & 6.327613 \\
\hline Pearson SSR & & & & $2.94 \mathrm{E}+12$ & \\
\hline Quasi-log likelihood & & & & $3.19 \mathrm{E}+12$ & \\
\hline Akaike info criterion & 5.681286 & 5.183774 & & & 5.351974 \\
\hline Durbin -Watson & 0.830314 & 1.534729 & 1.436670 & & \\
\hline Observations & 3,043 & 3,077 & 3,043 & 3,043 & 3,043 \\
\hline Hausman test & & Chi-Sq. Stat & tic $(0.000000)$, & rob. $(1.0000)$ & \\
\hline Loglikelihood test & Cross-se & tion F (Prob. 0.0 & 00), Cross-secti & Chi-square (Pro & $.0 .0000)$ \\
\hline
\end{tabular}

Note: Standard errors in parentheses. Statistical significance: $*<0.10$;

$* *<0.05 ; * * *<0.01$

Source: Authors' calculations 
In all estimated export models, remoteness is positive and significant, while PTA dummy is negative and significant only in the PPML model. Financial crisis dummy is significant only in a robust PPML estimator model.

Trade creation in exports from CEFTA (TCCD dummy) is significant under $1 \%$ significance level in all estimated models. Trade creation in exports from the EU membership (TCEUD) is negative in all models but significant only in a robust PPML model. Croatia had an increase in exports to CEFTA during CEFTA membership and a decrease in exports to the EU during the EU membership.

Trade diversion in exports from CEFTA (TDCD dummy) is significant under $1 \%$ significance level and positive only in a PPML model, in which trade diversion in exports from the EU (TDEUD dummy) is significant and positive. Croatia had been exporting more to RoW countries during CEFTA membership and more to RoW during the EU membership.

Under $1 \%$ significance level all models show a larger effect of trade creation than trade diversion in exports from CEFTA membership during the period 20002016 (TCCD > TDCD). An increase in exports to CEFTA is larger than to RoW during CEFTA membership. In terms of the EU membership, there is a negative significant effect of trade creation and a positive effect of trade diversion in the period 2000-2016. There had been a decrease in Croatia's exports to the EU during its membership and an increase in exports from the RoW. Under the EU membership, the dummy coefficients are larger for trade diversion than trade creation, in relative terms (TDEUD > TCEUD), signalling a decrease in exports into the EU member states compared to the RoW during the EU membership. Hence, based on the PPML model there is a trade diversion in terms of exports to the EU member states. 
Table 4.

\section{CROSS-COUNTRY PANEL REGRESSION FOR CROATIA'S TOTAL TRADE, 2000-2016}

\begin{tabular}{|c|c|c|c|c|c|}
\hline Dependent variable & \multicolumn{5}{|c|}{$(\log )$ Total trade } \\
\hline Indep. variable/Model & POLS & FE & RE & PPML & Tobit \\
\hline Constant & $\begin{array}{c}-105.9233 * * * \\
(23.08859)\end{array}$ & $\begin{array}{c}-43.40876 * * * \\
(6.004420)\end{array}$ & $\begin{array}{c}-103.7898 * * * \\
(16.98635)\end{array}$ & $\begin{array}{c}-69.39255 * * * \\
(0.000635)\end{array}$ & $\begin{array}{c}-105.9233 * * * * \\
(23.05047)\end{array}$ \\
\hline $\log$ GDP & $\begin{array}{c}4.450950^{* * *} \\
(0.730049)\end{array}$ & $\begin{array}{c}2.384911^{* * * *} \\
(0.252353)\end{array}$ & $\begin{array}{c}4.401099 * * * \\
(0.535494)\end{array}$ & $\begin{array}{c}3.202808 * * * \\
(2.01 \mathrm{E}-05)\end{array}$ & $\begin{array}{c}4.450950 * * * \\
(0.728843)\end{array}$ \\
\hline log Distance & $\begin{array}{c}-4.474453^{* * * *} \\
(0.733512)\end{array}$ & & $\begin{array}{c}-4.460676 * * * \\
(0.571764)\end{array}$ & $\begin{array}{c}-3.774497 * * * \\
(2.01 \mathrm{E}-05)\end{array}$ & $\begin{array}{c}-4.474453 * * * \\
(0.732301)\end{array}$ \\
\hline log Remoteness & $\begin{array}{c}3.134556^{* * * *} \\
(0.730618)\end{array}$ & & $\begin{array}{c}3.068379 * * * \\
(0.542118)\end{array}$ & $\begin{array}{c}2.495671 * * * \\
(2.00 \mathrm{E}-05)\end{array}$ & $\begin{array}{c}3.134556 * * * \\
(0.729411)\end{array}$ \\
\hline PTA & $\begin{array}{l}-0.000922 \\
(0.362140)\end{array}$ & & $\begin{array}{l}-0.124948 \\
(1.046921)\end{array}$ & $\begin{array}{c}-0.943037 * * * * \\
(8.66 \mathrm{E}-06)\end{array}$ & $\begin{array}{l}-0.000922 \\
(0.361542)\end{array}$ \\
\hline Financial crisis & $\begin{array}{l}-0.092766 \\
(0.133060)\end{array}$ & $\begin{array}{l}-0.001794 \\
(0.095114)\end{array}$ & $\begin{array}{l}-0.092697 \\
(0.097496))\end{array}$ & $\begin{array}{c}-0.132846 * * * \\
(3.46 \mathrm{E}-06)\end{array}$ & $\begin{array}{l}-0.092766 \\
(0.132840)\end{array}$ \\
\hline TCCD & $\begin{array}{c}2.651136 * * * \\
(0.410930)\end{array}$ & $\begin{array}{c}1.446975^{* * * *} \\
(0.345775)\end{array}$ & $\begin{array}{c}1.440038^{* * * *} \\
(0.339231)\end{array}$ & $\begin{array}{c}0.935761 * * * \\
(6.99 \mathrm{E}-06)\end{array}$ & $\begin{array}{c}2.651136^{* * * *} \\
(0.410251)\end{array}$ \\
\hline TDCD & $\begin{array}{l}0.273981^{*} \\
(0.155022)\end{array}$ & $\begin{array}{c}0.467639^{* * * *} \\
(0.107203)\end{array}$ & $\begin{array}{c}0.332699 * * * \\
(0.113943)\end{array}$ & $\begin{array}{c}0.223624 * * * \\
(4.63 \mathrm{E}-06)\end{array}$ & $\begin{array}{l}0.273981^{*} \\
(0.154766)\end{array}$ \\
\hline TCEUD & $\begin{array}{l}-0.063504 \\
(0.366753)\end{array}$ & $\begin{array}{c}0.437588 * \\
(0.248694)\end{array}$ & $\begin{array}{l}-0.172522 \\
(0.279462)\end{array}$ & $\begin{array}{c}-0.256542^{* * * *} \\
(6.57 \mathrm{E}-06)\end{array}$ & $\begin{array}{l}-0.063504 \\
(0.366147)\end{array}$ \\
\hline TDEUD & $\begin{array}{c}-1.221218 * * * \\
(0.250436)\end{array}$ & $\begin{array}{c}-0.806304 * * * \\
(0.151934)\end{array}$ & $\begin{array}{c}-1.178162 * * * \\
(0.184017)\end{array}$ & $\begin{array}{c}-0.012802 * * * \\
(8.00 \mathrm{E}-06)\end{array}$ & $\begin{array}{c}-1.221218^{* * * *} \\
(0.250023)\end{array}$ \\
\hline Adjusted R-squared & 0.655434 & 0.809381 & 0.232303 & & \\
\hline S.E. of regression & 2.884771 & 2.145759 & 2.115553 & & 2.884326 \\
\hline Prob. (F-statistic) & 0.00000 & 0.00000 & 0.00000 & & \\
\hline Mean dependent variable & 14.04496 & 14.02196 & 3.535489 & $1.62 \mathrm{E}+08$ & 14.04496 \\
\hline S.D. dependent variable & 4.914452 & 4.914712 & 2.414510 & $5.90 \mathrm{E}+08$ & 4.914452 \\
\hline Pearson SSR & & & & $2.34 \mathrm{E}+12$ & \\
\hline Quasi-log likelihood & & & & $9.71 \mathrm{E}+12$ & \\
\hline Akaike info criterion & 4.960049 & 4.423712 & & & 4.960706 \\
\hline Durbin -Watson & 0.670171 & 1.299311 & 1.237888 & & \\
\hline Observations & 3,043 & 3,077 & 3,043 & 3,043 & 3,043 \\
\hline Hausman test & & Chi-Sq. Stat & (0.000000), & rob. (1.0000) & \\
\hline Loglikelihood test & Cross-sect & on $\mathrm{F}$ (Prob. 0.00 & ), Cross-section & Chi-square $(\operatorname{Prc}$ & b. 0.0000$)$ \\
\hline
\end{tabular}

Note: Standard errors in parentheses. Statistical significance: $*<0.10 ; * *<0.05 ; * * *<0.01$.

Source: Authors' calculations 
Finally, in terms of total trade flows, variables remoteness, PTA and financial crisis have the same effect as in the import and export models. Trade creation in total trade flows with CEFTA (TCCD dummy) is significant under $1 \%$ significance level in all models. Trade creation from the EU membership (TCEUD) is significant and negative in the robust PPML model, implying a decrease in total trade flows with the EU. In terms of total trade flows, Croatia had a trade creation effect from CEFTA membership and a decrease in total trade flows with the EU during its EU membership.

Trade diversion in total trade flows with CEFTA (TDCD dummy) is significant and positive in all models, while trade diversion with the EU (TDEUD dummy) is significant and negative under $1 \%$ significance level in all models. There had been an increase in total trade flows with RoW under CEFTA, and a decrease in trade flows with the RoW under the EU membership.

In all models, trade creation is larger than trade diversion in the period 20002016 (TCCD > TDCD) from CEFTA membership. An increase in total trade flows had been greater within CEFTA than with the RoW, implying a trade creation from CEFTA membership. In terms of the EU membership, there is a negative effect of trade creation and trade diversion in the period 2000-2016. In the robust PPML model during the EU membership, there had been a decrease in total trade flows with the EU, and a decrease in the value of total trade flows with the RoW during the EU membership. Total trade flows had fallen more with the RoW than with the EU during the EU membership in the POLS, FE, RE and Tobit models implying a trade creation in total trade flows from the EU membership, while in the robust PPML model total trade flows with the RoW have fallen less than with the EU during the EU membership implying a trade diversion in total trade flows from the EU membership. Hence, the results about the trade creation and trade diversion effect in total trade flow from the EU membership are inconclusive.

\section{CONCLUSION}

The aim of this paper was to examine and model the trade creation and diversion effects of Croatia's CEFTA and EU membership in the period from 2000 to 2016. The Republic of Croatia's accession into regional economic integrations such as CEFTA and the EU should have had a positive impact on Croatia's trade flows. The hypothesis stated that the accession of the Republic of Croatia into CEFTA and the EU had positive effects on trade flows. The analysis found positive effects of Croatia-CEFTA integration evident in a dominant trade creation effect. The Croatia-EU integration exhibits trade diversion effect in cases of imports, exports, and is inconclusive in total trade flows. 
In terms of RE model, Croatia's membership in CEFTA resulted in trade creation in imports, exports and total trade flows. Regarding the EU membership, there is no evidence of trade creation in imports, exports or total trade flows. On the other hand, trade diversion from the EU membership is significant in the RE model, evident in a decrease of imports and total trade flows with the RoW, and insignificant in terms of exports from the RoW.

A Tobit estimator model is similar to RE model. Trade creation in imports, exports and total trade flows from CEFTA membership is present. In terms of a Tobit estimator's trade creation and trade diversion effects from the EU membership, there is a significant effect of trade diversion in imports and total trade flows, a lack of evidence of trade creation with the EU, and no significant support of trade creation or diversion in exports to the EU.

Finally, the robust PPML estimator displays: (1) CEFTA membership in trade creation in imports, exports and total trade flows, and (2) the EU membership's trade diversion in imports and exports, and trade creation in total trade flows. Positive effects of trade creation occur when domestic production is replaced with imports of cheaper products of a more efficient producer from the PTAs. It can be stated that a robust PPML estimator shows a trade creation in total trade flows from both CEFTA and the EU membership. Hence, domestic production is replaced with products from the regional trade partners.

Implications for the policy arise in several areas including trade, competition, investment, capital movements and intellectual property rights protection. For the Republic of Croatia all mentioned policies are formed on the European Union level and enforced through directives onto the national level. As the European Union member state, the Republic of Croatia should support service, as well as goods, export policies that benefit its trade creation, while take care to diminishing the negative effects of import policies that cause its trade diversion. Based on the PPML estimator, Croatia had been experiencing trade diversion in imports and exports to the European Union, which implies that Croatian manufacturers focused on the European Union market due to the abolition of tariffs. Further studies should attempt to find whether this is because cheaper intermediate goods are sold onto the EU market. If this is the case, the increase in innovation and investment is necessary to step up in the European Union value chains. Moreover, as Croatia imports more from the EU and exports more to the RoW, we could pose the question of branding and quality as perceived from the EU membership.

Limitations of this study are related to an uneven number of countries in the two regional economic integrations in the observed period, especially for CEFTA countries and global economic recession, which decreased overall trade flows disabling the identification of trade creation and trade diversion effects' causalities. 
Further research should include the analysis of CEFTA and the EU economic integrations on the trade flows of all EU member states and with respect to particular goods and/or industries. Moreover, as this paper studies Croatia's trade creation and trade diversion effects from CEFTA and the EU membership prior the introduction of the single currency, it will be interesting to observe the change in welfare effects after Croatia joins the ERM II and European Monetary Union.

\section{REFERENCES}

1. Adam, C., Cobham, D. (2007). Modelling multilateral trade resistance in a gravity model with exchange rate regimes. Centre for dynamic macroeconomic analysis conference papers. Available at: https://ideas.repec.org/p/san/ cdmacp/0702.html [27 December 2019].

2. Akram, M., Rashid, A. (2017). Trade Creation and Diversion Effects of the European Union. Pakistan Journal of Applied Economics Special Issue, December 2016.

3. Anderson, J. E., Van Wincoop E. (2003). Gravity with gravitas: A solution to the border puzzle. The American Economic Review, 93, 170-92.

4. Balassa, B. (1961). Towards a theory of economic integration. Kyklos, 14, 1-17.

5. Balassa, B. (1974). Trade creation and trade diversion in the European Common Market: An appraisal of the evidence. The Manchester School of Economic \& Social Studies, 42(2), 93-135.

6. Baldwin, R. (2016). The World Trade Organisation and the future of multilateralism. Journal of Economic Perspectives, 30(1), 95-116.

7. Bilenko, Y. (2013). Dynamic Economic Effects of EU Membership for Post Socialist Countries of Central and Eastern Europe. Wroclaw Review of Law, Administration \& Economics, 3(1), 90-103.

8. Ćudina, A., Sušić, G. (2013) Utjecaj pristupanja Hrvatske Europskoj uniji na trgovinske i gospodarske odnose sa zemljama CEFTA-e. Ekonomski pregled, 64(4), 376-396.

9. De Boyrie, M.E., Kreinin, M. (2016). Regional integration in Latin America. Global Economy Journal, 16(2), 293-311.

10. Buigut, S. (2016). Trade effects of the East African Community customs union: Hype versus reality. South African Journal of Economics, 84(3), 422-439.

11. Clausing, K. (2001). Trade Creation and Trade Diversion in the Canada United States Free Trade Agreement. The Canadian Journal of Economics/ Revue Canadienne D'Economique, 34(3), 677-696. 
12. Damijan, J. P., Masten, I. (2002). Time Dependent Efficiency of Free Trade Agreements: The Case of Slovenia and the CEFTA Agreement. The Economic and Social Review, 33(1), 147-160.

13. Damijan, J. P., de Sousa, J., Lamotte, O. (2006). The Effect of Trade Liberalization in South-Eastern European Countries. The WIIW Balkan Observatory Working Papers/0701.

14. Deme, M., Ndrianasy, E.R. (2017). Trade-creation and trade-diversion effects of regional trade arrangements: low-income countries. Applied Economics, 49(22), 2188-2202.

15. Derado, D. (2008). Effects of the Eastern EU-enlargement on Croatia - a trade analysis. Management, 13(1), 37-58.

16. DistanceFromTo (2018). Distance between cities places on map. Available at: https://www.distancefromto.net/ [27 December 2018].

17. Eicher, T., Henn, C., Papageorgiou C. (2008). Trade Creation and Diversion Revisited: Accounting for Model Uncertainty and Natural Trading Partner Effects. IMF Working Paper WP/08/66. Available at: https://onlinelibrary. wiley.com/doi/abs/10.1002/jae.1198 [27 December 2018].

18. Esposito, P. (2017). Trade creation, trade diversion and imbalances in the EMU. Economic Modelling, 60, 462-472.

19. Fukao, K. Okubo, T., Stern, R. M. (2002). An Econometric Analysis of Trade Diversion under NAFTA. Discussion Paper No. 491.

20. Gauto, V. F. (2012). An Econometric Analysis of Trade Creation and Trade Diversion in Mercosur: the Case of Paraguay. 2012 Conference, August 18-24, 2012, Foz do Iguacu, Brazil 126864, International Association of Agricultural Economists.

21. Ghazalian, P.L. (2017). The effects of NAFTA/CUSFTA on agricultural trade flows: An empirical investigation. Canadian Journal of Agricultural Economics-Revuew Canadienne D Agroeconomie, 65(2), 219-248.

22. Government of the Republic of Croatia and the Croatian National Bank (2018). Strategija za uvođenje eura kao službene valute u Hrvatskoj. Available at: http://euro.hnb.hr/documents/2070751/2104255/h-strategija-za-uvodenje-eura-kao-sluzbene-valute-u-HR.pdf/ [27 December 2018].

23. Haveman, J., Hummels, D. (1998). Trade Creation and Trade Diversion, Journal of Transnational Management Development, 3(2), 47-72.

24. Head, K. (2003). Gravity for beginners, University of British Columbia.

25. Jošić, H., Jošić, M. (2013). Static and dynamic effects of customs union creation. Conference Proceedings, Vinko Kandžija, Andrej Kumar (eds.). Opatija: University of Rijeka, 2013, 53-65. 
26. Kandogan, Y. (2005). Trade Creation and Diversion Effects of Europe's Regional Liberalization Agreements. William Davidson Institute Working Paper Number 746 Available at: https://www.tandfonline.com/doi/ abs/10.1080/10168730903372257 [27 December 2018].

27. Kar, M. (2018). Economic integration and trade protection: Policy issues for South Asian countries. Contemporary Economic Policy, 36(1), 167-182.

28. Karaman, F., Ozkale, L. (2006). Static Effects of the EU-Turkey Customs Union. Journal of International Trade and Diplomacy, 1, 117-138. Available at: https://ssrn.com/abstract=2218980 [27 December 2018].

29. Koo, W., Kennedy, P., Skripnitchenko, A. (2006). Regional Preferential Trade Agreements: Trade Creation and Diversion Effects. Review of Agricultural Economics, 28(3), 408-415.

30. Krueger, A. O. (1999). Trade Creation and Trade Diversion Under NAFTA, NBER Working Paper No. 7429, Issued in December 1999. Available at: http://www.nber.org/papers/w7429 [27 December 2018].

31. Linders, G-J. M., de Groot, H. L. F. (2006). Estimation of the Gravity Equation in the Presence of Zero Flows, TI 2006-072/3 Tinbergen Institute Discussion Paper. Available at: https://papers.tinbergen.nl/06072.pdf [27 December 2019].

32. Lugman, A., O., Abu Bakar, N.A., Izraf, A.A.M. (2016). The gravity model approach: An application on the ECOWAS trading bloc. South East European Journal of Economics and Business, 11(1), 67-75.

33. Magee, C. S. P. (2016). Trade creation, trade diversion, and the general equilibrium effects of regional trade agreements: a study of the European CommunityTurkey customs union. Review of World Economics, 152, 383-399.

34. Majcen, B., Verbič, M., Knežević, S. (2007). The Effects of Foreign Trade Liberalisation and Financial Flows between Slovenia and the EU after Accession. Post-Communist Economies, 17 (2), 251-267.

35. Majkovič, D., Bojnec, Š., Turk, J. (2007). Development of New Members' EU Trade: Evidence from the Slovenian Agri-Food Sector. Post-Communist Economies, 19 (2), 209-223.

36. Martin-Mayoral, F., Moran Carofilis, G., Cajas Guijarro, J. (2016). The effects of integration agreements in Western hemisphere trade, 1970-2014. Journal of International Trade \& Economic Development, 25(5), 724-756.

37. Michalopoulos, C., Tarr, D. (2004). Are Customs Unions Economically Sensible in the Commonwealth of Independent States. World Bank, Washington, DC. Available at: https://openknowledge.worldbank.org/handle/10986/25932 [27 December 2018]. 
38. Mitaj, A., Osmani, M. (2017). Trade creation and trade diversion effects for Albania in the framework of CEFTA membership: A panel data econometric analysis. International Journal of Economics, Commerce and Management, 5(12), ISSN 23480386.

39. Mölders, F., Volz, U. (2011). Trade creation and the status of FTAs: empirical evidence from East Asia. Review of World Economics, 147(3), 429-456.

40. Morais, A. G., Bender, S. (2006). Trade Creation And Trade Diversion In Mercosur And Nafta. Anais do XXXIV Encontro Nacional de Economia [Proceedings of the 34th Brazilian Economics Meeting]122, ANPEC Associa Ã $\tilde{A} £$ o Nacional dos Centros de PÃ ${ }^{3}$ s-GraduaÃ $\tilde{A} £ o$ em Economia [Brazilian Association of Graduate Programs in Economics].

41. Ngepah, N., Udeagha, M.C. (2018). African regional trade agreements and intra-African trade. Journal of Economic Integration, 33(1), 1176-1199.

42. Yang, S., Martínez-Zarzoso, I. (2013). A Panel Data Analysis of Trade Creation and Trade Diversion Effects: The case of ASEAN-China Free Trade Area (ACFTA). Ibero America Institute for Econ. Research (IAI) Discussion Papers 224, Ibero-America Institute for Economic Research.

43. Santos Silva, J., Tenreyro, S. (2006). The log of gravity, The Review of Economics and Statistics, 88: 641-58.

44. Santos Silva, J.M.C.; Tenreyro, S. (2011). Further simulation evidence on the performance of the Poisson pseudo-maximum likelihood estimator. Economics Letters, 112(2), 220-222. doi:10.1016/j.econlet.2011.05.008.

45. Ranilović, N. (2017). The Effects of Economic Integration on Croatian Merchandise Trade: A Gravity Model Study. Comparative Economic Studies, 59(3), 382-404.

46. Susanto, D., Parr Rosson, C. III, Adcock, F. J. (2007). Trade Creation and Trade Diversion in the North American Free Trade Agreement: The Case of the Agricultural Sector. Journal of Agricultural and Applied Economics, 39(1), 121-134.

47. Štulec, I., Vučković, V., Baković, T. (2014). Impact of Croatian EU accession on its foreign trade and customs system. Ekonomski vjesnik/Econviews, 27(2), 381-392.

48. Taguchi, H. (2015). Trade creation and diversion effects of ASEAN-plus-one free trade agreements, Economics Bulletin, 35(3), 1856-1866.

49. Teteryanikova, M. (2018). R\&D in trade networks: The role of asymmetry. International Journal of Industrial Organization, 61(SI), 307-350.

50. Tinbergen, J. (1962). An Analysis of World Trade Flows. In Shaping the World Economy, edited by Jan Tinbergen. New York, NY: Twentieth Century Fund. 
H. JOŠIĆ, M. BAŠIĆ: Trade creation and trade diversion effects from Croatia's CEFTA and EU membership EKONOMSKI PREGLED, 72 (4) 489-521 (2021)

51. Tobin, J. (1958). Estimation of Relationships for Limited Dependent Variables. Econometrica, 26 (1), 24-36.

52. Urata, S., Okabe, M. (2010). Trade Creation and Diversion Effects of Regional Trade Agreements on Commodity Trade. RIETI Discussion Paper Series 10E-007 January 2010.

53. Uzair, L., Nawaz, A. (2018). Modelling welfare effects under Pakistan-China free trade agreement. Journal of Chinese Economic and Foreign Trade, 11(3), 202-218.

54. Viner, J. (1950). The customs union issue. New York: Carnegie Endowment for International Peace.

55. Westerlund, J., Wilhelmsson, F. (2011). Estimating the gravity model without gravity using panel data. Applied Economics, 43(6), 641-649.

56. World Bank (2018). Gross domestic product of Croatia and trading countries. Available at: https://data.worldbank.org/indicator/NY.GDP.MKTP.CD [27 December 2018].

57. World Integrated Trade Solution (2018). Croatia import, export and trade. Available at: https:/wits.worldbank.org/CountryProfile/en/Country/HRV/ StartYear/2000/EndYear/2016/TradeFlow/Import/Partner/ALL/Indicator/ MPRT-TRD-VL [27 December 2018].

58. World Integrated Trade Solution (2019). Croatia import, export and trade. Available at: https://wits.worldbank.org/CountryProfile/en/Country/HRV/ [29 December 2019].

59. WTO (2019). Regional Trade Agreements Information System. Available online at: http://rtais.wto.org/UI/PublicAllRTAList.aspx [26 January 2019]. 


\section{Appendix 1}

Figure Al.

CEFTA AND EU MEMBER COUNTRIES (DE)ACCESSION DATES

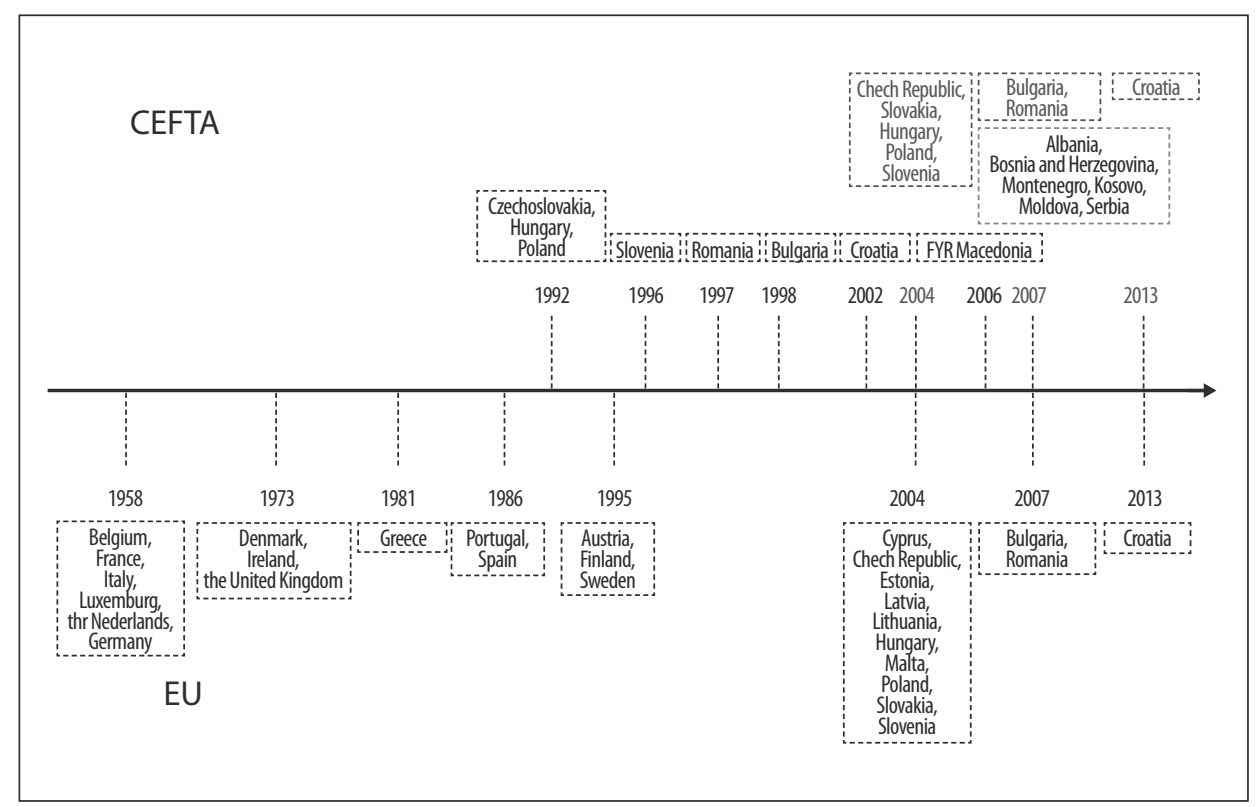

Source: Authors' illustration 
H. JOŠIĆ, M. BAŠIĆ: Trade creation and trade diversion effects from Croatia's CEFTA and EU membership EKONOMSKI PREGLED, 72 (4) 489-521 (2021)

\title{
UČINCI STVARANJA I SKRETANJA TRGOVINE IZ ČLANSTVA HRVATSKE U CEFTA-I I EU
}

\begin{abstract}
Sažetak
Ovaj rad je detaljna empirijska studija učinaka stvaranja i skretanja trgovine koji proizlaze iz dvaju regionalnih trgovinskih sporazuma Hrvatske, Srednjoeuropskog sporazuma o slobodnoj trgovini (CEFTA) i Europske unije (EU), omogućujući tako temelje za buduće rasprave o trgovinskim politikama u pogledu koristi i nedostataka regionalnih trgovinskih sporazuma. Trgovinski tokovi sa 180 zemalja vanjskotrgovinskih partnera analizirani su za razdoblje od 2000. do 2016. godine za uvoz, izvoz i ukupne trgovinske tokove. Korištenjem među-državne panel regresijske analize i korištenjem gravitacijskog modela međunarodne trgovine, procijenjeni su združeni OLS, model fiksnih i random efekata, kao i robusniji Tobit i PPML modeli procjene. Model random efekata pokazao je pozitivne učinke integracije Hrvatske i CEFTA-e uočljive u učinku stvaranja trgovine za uvoz, izvozu i ukupne trgovinske tokove. Integracija Hrvatske u EU nije pokazala značajan utjecaj na stvaranje trgovine u uvozu, izvozu niti u ukupnim trgovinskim tokovima, ali postoji utjecaj preusmjeravanja trgovine u slučaju uvoza i ukupnih trgovinskih tokova. U modelu Tobita CEFTA je pokazala efekt stvaranja trgovine u uvozu, izvozu i ukupnim trgovinskim tokovima i skretanje trgovine u uvozu i ukupnim trgovinskim tokovima uslijed članstva $u$ EU. Konačno, pomoću robusnog PPML-a procjenitelja, studija je utvrdila: (1) članstvo u CEFTA-i stvorilo je trgovinu и uvozu, izvozu i ukupnim trgovinskim tokovima, $i$ (2) članstvo $u$ EU-u imalo je efekt skretanja u uvozu, izvozu i stvaranje trgovine u ukupnim trgovinskim tokovima.
\end{abstract}

Ključne riječi: stvaranje trgovine; skretanje trgovine; Hrvatska; CEFTA; EU; gravitacijski model 